\title{
Potential Effects of Climate Change on Streamflow, Eastern and Western Slopes of the Sierra Nevada, California and Nevada
}

By Anne E. Jeton, Michael D. Dettinger, and J. LaRue Smith

\section{U.S. GEOLOGICAL SURVEY}

Water-Resources Investigations Report 95-4260

$\frac{\infty}{n}$ 


\section{U.S. DEPARTMENT OF THE INTERIOR \\ BRUCE BABBITT, Secretary}

U.S. GEOLOGICAL SURVEY

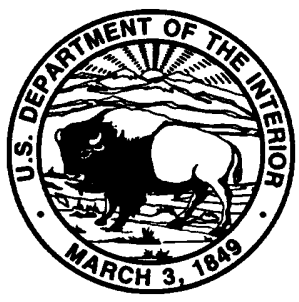

Gordon P. Eaton, Director

The use of firm, trade, and brand names in this report is for identification purposes only and does not constitute endorsement by the U.S. Geological Survey.

For additional information write to:

District Chief

U.S. Geological Survey

Federal Building, Room W-2233

2800 Cottage Way

Sacramento, CA 95825
Copies of this report can be purchased from:

U.S. Geological Survey

Earth Science Information Center

Open-File Report Section

Box 25286, Mail Stop 417

Denver Federal Center

Denver, CO 80225 


\section{CONTENTS}

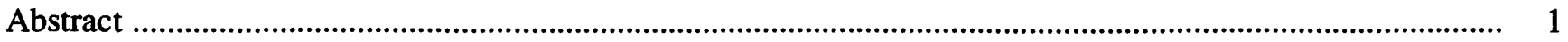

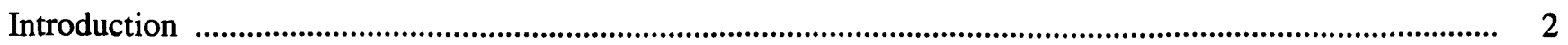

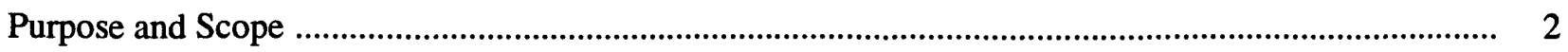

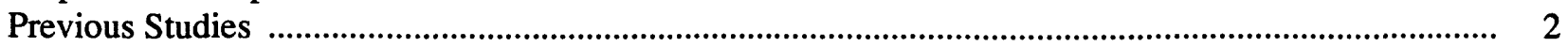

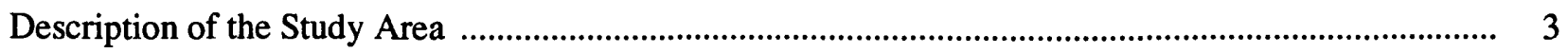

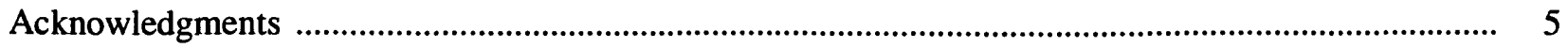

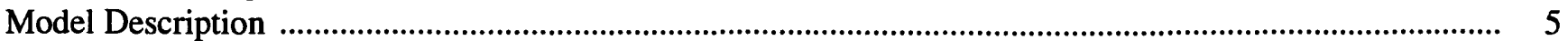

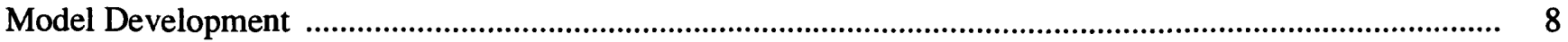

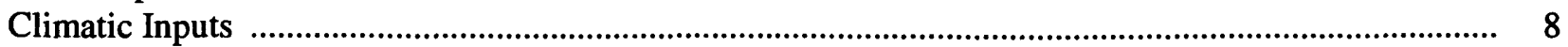

Hydrologic Response Unit Delineation Using a Geographic Information System ............................... 9

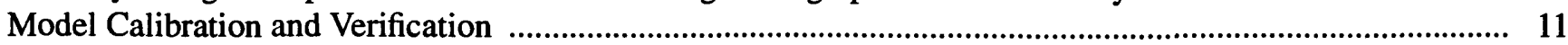

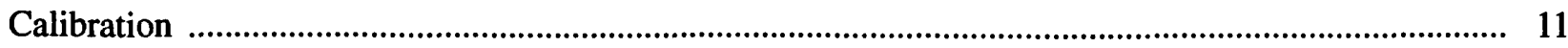

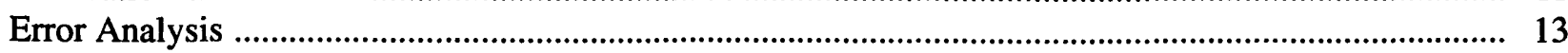

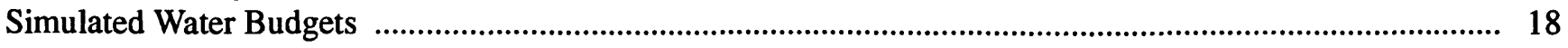

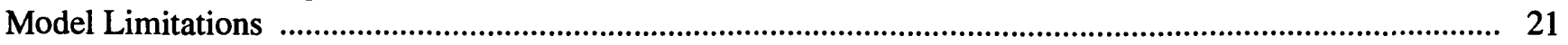

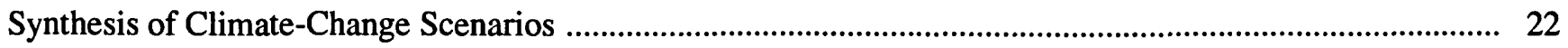

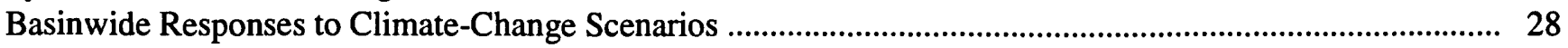

Responses to Changed Precipitation Scenarios .................................................................................. 29

Responses to Changed Temperature Scenarios .............................................................................. 30

Responses to Simultaneous Changes in Precipitation and Temperature .............................................. 33

Responses to General Circulation Climate-Model Projections ........................................................... 37

Coupling of Sublimation-Evapotranspiration and Snowmelt ........................................................... 38

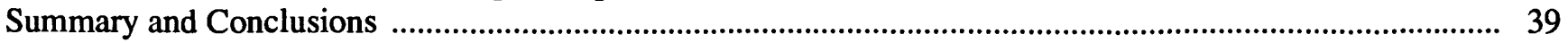

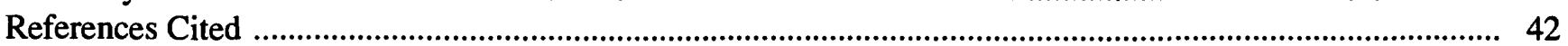

\section{FIGURES}

1. Map showing location of East Fork Carson River basin (above Markleeville, California) and North Fork American River Basin (above North Fork Dam) ................................................... 4

2. Graph showing distribution of altitudes in the North Fork American and East Fork Carson River basins

3. Schematic diagram for Precipitation-Runoff Modeling System

4. Diagram showing steps in basin characterization and hydrologic response unit (HRU) delineation

5. Map showing subset of hydrologic response units (HRU) for East Fork Carson River basin

6-18. Graphs showing:
6. Observed and simulated mean annual flows for East Fork Carson River for water years 1969-90

7. Mean monthly streamflow for East Fork Carson River basin as percentage of annual streamflow for the calibration (1980-90) and verification (1969-79) periods

8. Observed and simulated mean annual flows for North Fork American River for water years 1949-90

9. Mean monthly streamflow for North Fork American River basin as percentage of annual streamflow for the calibration (1969-90) and verification (1949-68) periods 
10. Hydrographs of daily mean flows for East Fork Carson and North Fork American River basins for water years 1977 and 1983

11. Flow-duration curves for observed and simulated daily streamflow for 1969-90 for East Fork Carson and North Fork American Rivers

12. Monthly distribution of water-budget components for East Fork Carson and North Fork American River basins for water years 1969-90

13. Historical and synthetic current-condition climates (precipitation and potential evapotranspiration) as distributed and areally averaged by streamflow model

14. Simulated mean streamflows under scenarios in which mean precipitation is changed for East Fork Carson and North Fork American Rivers

15. Simulated water-budget responses to uniform-change scenarios in the East Fork Carson River basin

16. Simulated water-budget responses to uniform-change scenarios in the North Fork American River basin

17. Simulated streamflow-timing responses to uniform-change scenarios as a function of changes in mean temperature and mean precipitation

18. Simulated changes in annual sum of sublimation, evapotranspiration, and interception losses (SET) as a function of changes in mean temperature and mean precipitation

\section{TABLES}

1. Grouped GIS data for the East Fork Carson River basin

2. Annual statistics for the East Fork Carson River streamflow

3. Observed and simulated monthly runoff for the East Fork Carson River basin, as a percentage of annual streamflow

4. Annual statistics for the North Fork American River streamflow

5. Observed and simulated monthly runoff for the North Fork American River basin, as a percentage of annual streamflow

6. Simulated annual water budget for 1969-90 for the Carson and American River models

7. Mean historical-condition and current-condition estimates of components of annual water budget for the East Fork Carson River, and simulated changes in these components under climate-change conditions (relative to the current-condition estimates)

8. Mean historical-condition and current-condition estimates of components of annual water budget for the North Fork American River, and simulated changes in these components under climate-change conditions (relative to the current-condition estimates) 
CONVERSION FACTORS AND VERTICAL DATUM

\section{Conversion Factors}

\begin{tabular}{rll}
\hline Multiply & By & To obtaln \\
\hline centimeter $(\mathrm{cm})$ & 0.3937 & inch \\
cubic centimeter $\left(\mathrm{cm}^{3}\right)$ & 0.06102 & cubic inch \\
cubic meter per second $\left(\mathrm{m}^{3} / \mathrm{s}\right)$ & 35.31 & cubic foot per second \\
gram $(\mathrm{g})$ & 0.03527 & ounce avoirdupois \\
hectare $(\mathrm{ha})$ & 2.471 & acre \\
meter $(\mathrm{m})$ & 3.281 & foot \\
millimeter $(\mathrm{mm})$ & 0.03937 & inch \\
kilometer $\left(\mathrm{km}^{2}\right)$ & 0.6214 & mile \\
square kilometer $\left(\mathrm{km}^{2}\right)$ & 0.3861 & square mile \\
\hline
\end{tabular}

Temperature: Degrees Celsius $\left({ }^{\circ} \mathrm{C}\right)$ can be converted to degrees Fahrenheit $\left({ }^{\circ} \mathrm{F}\right)$ by using the formula ${ }^{\circ} \mathrm{F}=\left[1.8\left({ }^{\circ} \mathrm{C}\right)\right]+32$.

\section{Vertical Datum}

Sea level: In this report, "sea level" refers to the National Geodetic Vertical Datum of 1929 (NGVD of 1929, formerly called "Sea-Level Datum of 1929"), which is derived from a general adjustment of the first-order leveling networks of the United States and Canada. 


\title{
Potential Effects of Climate Change on Streamflow, Eastern and Western Slopes of the Sierra Nevada, California and Nevada
}

\author{
By Anne E. Jeton, Michael D. Dettinger, and J. LaRue Smith
}

\section{Abstract}

Precipitation-runoff models of the East Fork Carson and North Fork American Rivers were developed and calibrated for use in evaluating the sensitivity of streamflow in the northcentral Sierra Nevada to climate change. The East Fork Carson River drains part of the rainshadowed, eastern slope of the Sierra Nevada and is generally higher than the North Fork American River, which drains the wetter, western slope. First, a geographic information system was developed to describe the spatial variability of basin characteristics and to help estimate model parameters. The result was a partitioning of each basin into noncontiguous, but hydrologically uniform, land units. Hydrologic descriptions of these units were developed and the Precipitation-Runoff Modeling System (PRMS) was used to simulate water and energy balances for each unit in response to daily weather conditions. The models were calibrated and verified using historical streamflows over 22-year (Carson River) and 42year (American River) periods.

Simulated annual streamflow errors average plus 10 percent of the observed flow for the East Fork Carson River basin and plus 15 percent for the North Fork American River basin. Interannual variability is well simulated overall, but, at daily scales, wet periods are simulated more accurately than drier periods. The simulated water budgets for the two basins are significantly different in seasonality of streamflow, sublimation, evapotranspiration, and snowmelt. The simulations indicate that differences in snowpack and snowmelt timing can play pervasive roles in determining the sensitivity of water resources to climate change, in terms of both resource availability and amount.

The calibrated models were driven by more than 25 hypothetical climate-change scenarios, each 100 years long. The scenarios were synthesized and spatially disaggregated by methods designed to preserve realistic daily, monthly, annual, and spatial statistics. Simulated streamflow timing was not very sensitive to changes in mean precipitation, but was sensitive to changes in mean temperatures. Changes in annual streamflow amounts were amplified reflections of imposed mean precipitation changes, with especially large responses to wetter climates. In contrast, streamflow amount was surprisingly insensitive to mean temperature changes as a result of temporal links between peak snowmelt and the beginning of warm-season evapotranspiration. Comparisons of simulations driven by temporally detailed climate-model changes in which mean temperature changes vary from month to month and simulations in which uniform climate changes were imposed throughout the year indicate that the srowpack accumulates the influences of short-term conditions so that season 
average climate changes were more important than shorter term changes.

\section{INTRODUCTION}

Global changes in climate attributed to increased concentrations of greenhouse gases have been the subject of numerous investigations over the past decade. The range of responses by general circulation models to plausible increases in concentrations of atmospheric carbon dioxide and other trace gases suggests that climatic responses eventually may significantly affect regional hydrologic processes. Simulated global average climate changes vary from +2 to $+5^{\circ} \mathrm{C}$ for temperature and from +7 to +15 percent for precipitation (Mitchell and others, 1991). Regional changes, however, are less certain and exhibit great variability from model to model (Waggoner, 1990). The changes are particularly important in parts of the Western United States where water supplies are near or past the point of overdraft and already are subject to flood and drought. Although historical climatic and water-supply fluctuations are often assumed to be valid guides to future variability, if climate changes, the adequacy of supplies may have to be reassessed. These reassessments ultimately depend upon our ability to project the size and type of hydrologic responses to expected climate changes. In response to concerns about the possible effects of such changes, river basin scale studies of sensitivities of water resources have been undertaken by the U.S. Geological Survey as part of its Global Change Research Program.

\section{PURPOSE AND SCOPE}

The purpose of this study was to determine how hydrologic processes differ between the western and eastern slopes of the Sierra Nevada under historical conditions and future climate-change scenarios. Particular attention was given to changes in distribution and timing of snowmelt runoff, a resource crucial to meet the agricultural and industrial-municipal water needs for California and Nevada. Descriptions of the basins, the models, and their responses to climate variability and change are presented in this report. The report describes the development and calibration of precipitation-runoff models for the East Fork Carson and North Fork American Rivers. It includes a description of digital methods for characterizing the basins, followed by a description of the calibration and verification of the two watershed models. The simulated water budgets are then compared and the potential limitations of the models in applications to climate-change scenarios are discussed. The report describes the synthesis of climate-change scenarios, presents river basin simulations, and discusses the simulated hydrologic responses. The summary and conclusions discuss broader implications of these results.

\section{PREVIOUS STUDIES}

This study uses models that represent more of the physical complexity and spatial variability within the basins than previous studies and thus may provide further elaboration of physical mechanisms and responses observed in simpler models. The previous studies focused on changes in runoff timing under mean-temperature changes, deriving conclusions that are mostly corroborated by the present study. Several studies have applied precipitation change and temperature change estimates derived from general circulation models to historically calibrated regional waterbudget analyses (Flaschka and others, 1987; Lettenmaier and Gan, 1990; Nash and Gleick, 1991; Lettenmaier and Sheer, 1991; Troendle, 1991; Tsuang and Dracup, 1991). Results from these studies indicate that changes in regional temperatures and precipitation patterns can result in reduced winter and spring snowwater equivalent due to decreased snowpack accumulation; shifted timing of streamflow from late spring to late winter-early spring, possibly characterized by a steeper hydrograph and a longer recession curve; and increased winter flooding due to more occurrences of rain-on-snow.

Regional water-budget analyses such as those described by Gleick (1978a, b) and Lettenmaier and Gan (1990) produce satisfactory results at both annual and monthly scales. However, in these regional models, physical processes and hydrologic components typically are drastically simplified and spatially lumped. Some of the processes that are potentially misrepresented by such simplifications are canopy interception, sublimation, snowpack accumulation and melt, multi-zoned soil moisture storage, evapotranspiration, and subsurface flow routing. However good the calibration of regional models to historical records, the simplifications made in regional studies may have affected the climate-change sensitivities. For exam- 
ple, climate change could affect evapotranspiration rates differently in different parts of the basins, which in turn would affect the distribution and timing of streamflow (Lettenmaier and Gan, 1990; Nash and Gleick, 1991; Kite, 1992). Thus, confident depictions of climate-change responses require models and topographic, soil, and vegetation data sufficient to delineate subbasin variability.

Statistical approaches (for example, Cayan and Riddle, 1992) also have been applied to describe generalized hydrologic responses to hypothetical climate changes. However, these approaches do not directly incorporate the interlocking physical mechanisms and spatial-temporal detail of river basin processes and thus typically may not be applicable to describe hydrologic responses to climate forcings not previously encountered in the historical record. Physically based models have the advantage, in this regard, that they are specifically designed to represent hydrologic responses to wide ranges of climate conditions, often wider ranges than are encountered in any single basin.

\section{DESCRIPTION OF THE STUDY AREA}

Two basins representative of climatic and physiographic variability of much of the Sierra Nevada were selected for hydrologic analyses and simulation. The two basins were the East Fork Carson River basin, which drains part of the rain-shadowed, eastern slope of the Sierra Nevada, and the North Fork American River basin, which drains the wetter, western slope (fig. 1).

The East Fork Carson River (hereafter referred to as the Carson River) drains $714 \mathrm{~km}^{2}$ of the upper catchment of the greater Carson River basin. Mean annual precipitation in the Carson River basin ranges from $559 \mathrm{~mm}$ at Woodfords (altitude $1,722 \mathrm{~m}$ ) to $1,244 \mathrm{~mm}$ at Twin Lakes (altitude $2,438 \mathrm{~m}$ ) (both climate stations are outside of, but near, the basin). Mean annual minimum and maximum temperatures average from $2{ }^{\circ} \mathrm{C}$ and $17^{\circ} \mathrm{C}$ at Woodfords to $-2^{\circ} \mathrm{C}$ and $11^{\circ} \mathrm{C}$ at Twin Lakes, respectively. Grasslands, chaparral-sagebrush rangelands, juniper woodlands, and mountain-conifer forest occur successively upslope from the valley floor. Moderately deep to shallow, gravelly sandy, and clayey soils reflect bedrock material, which is dominantly volcanic rocks and granodiorite. Highly fractured, bedrock-controlled ero- sion surfaces contribute steep slopes. Although the Carson River basin has experienced changes in vegetation cover due to timber harvesting and fires during the period of streamflow records, effects on water yield were assumed to be negligible in this study.

The North Fork American River (hereafter referred to as the American River) drains an $886-\mathrm{km}^{2}$ basin on the western slope of the Sierra Nevada. Mean annual precipitation in the American River basin varies from $813 \mathrm{~mm}$ at Auburn (altitude $393 \mathrm{~m}$ ) to $1,651 \mathrm{~mm}$ at Blue Canyon (altitude $1,676 \mathrm{~m}$ ), above which it apparently stabilizes up to at least $2,100 \mathrm{~m}$. Mean annual minimum and maximum temperatures range from $8{ }^{\circ} \mathrm{C}$ and $22^{\circ} \mathrm{C}$ at Auburn to $-3^{\circ} \mathrm{C}$ and 11 ${ }^{\circ} \mathrm{C}$ at the Central Sierra Snow Lab weather station $(2,103 \mathrm{~m})$. Vegetation varies upslope through pineoak woodlands, shrub rangeland, ponderosa pine, and subalpine forest. Soils are dominantly clay loams and coarse sandy loams reflecting variable bedrock material that includes metasedimentary rocks and granodiorite. In contrast to the Carson River basin, the American River basin has been actively harvested for timber, particularly in the late 1800 's in response to the area's mining boom, resulting in secondary-growth forests throughout much of the basin.

Both river basins are largely unregulated by reservoirs or diversions upstream from where flow has been measured. Because of the rain-shadow effect of the Sierra, the Carson River basin receives 33 percent less precipitation on average than the American River basin. This investigation was intended to provide insight into climate-change sensitivities on the wet and dry slopes all along the west coast of North America. However, the differences between the basins and, indeed, between the east and west slopes of the Sierra Nevada are not limited to the rain-shadow effect. The basins also differ in altitudes, slopes of the mountainrange face, and large-scale orientation of the rivers in the areas modeled.

The American River basin ranges between 200 $\mathrm{m}$ above sea level near Auburn and almost 2,700 $\mathrm{m}$ at the basin crest (fig. 2). The Carson River basin is restricted to altitudes above $1,650 \mathrm{~m}$ near Markleeville and reaches about $3,400 \mathrm{~m}$ at the basin crest (fig. 2). As a consequence, the Carson River basin is generally cooler than the American River basin. The Carson River basin is a high altitude, snow-dominated hydro- 

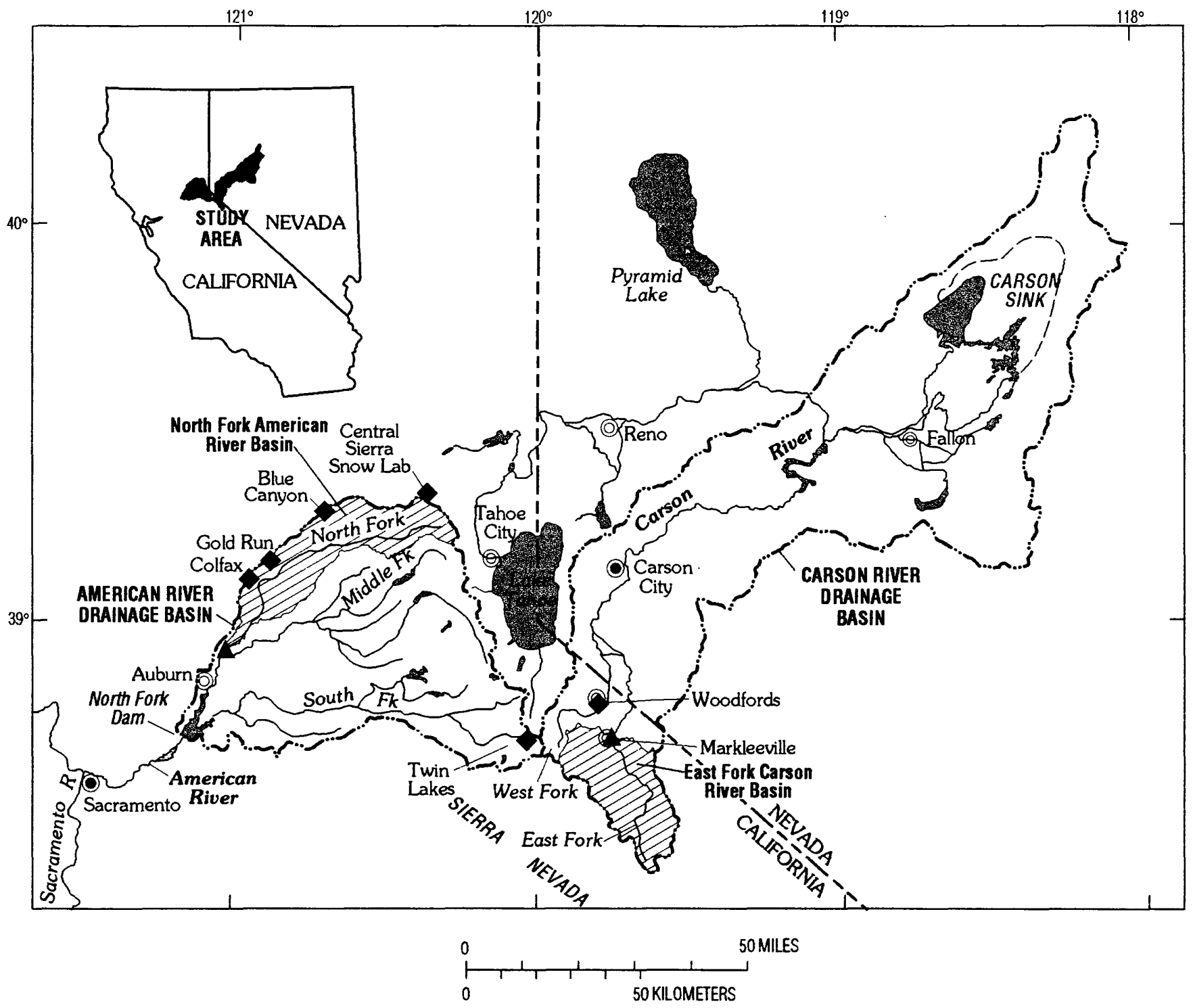

\section{EXPLANATION}

\section{A Streamflow gaging station \\ Twin Weather station and name}

Figure 1. Location of East Fork Carson River basin (above Markleeville, California) and North Fork American River Basin (above North Fork Dam).

logic system; in contrast, the American River basin is dominated by rain and mixed snow and rain. In both basins, approximately 80 percent of the annual precipitation occurs between November and March, but the importance and timing of snowmelt reflects differences in the percent of basin area above and below the snow line. In the eastern Sierra, the snowline lies at a seasonal average of $1,980 \mathrm{~m}$ and in the western Sierra at 1,675 m. Eighty-eight percent of the Carson River basin is above the eastern snowline, whereas only about 40 percent of the American River basin lies above its snowline. Winter precipitation in the Carson River basin is stored mostly as snowpack and runs off months later during a brief snowmelt peak in late spring. Winter precipitation in the American River basin includes both rain and mixtures of snow and rain. The result is intermittent snowmelt periods concurrent with the winter precipitation period, plus a 


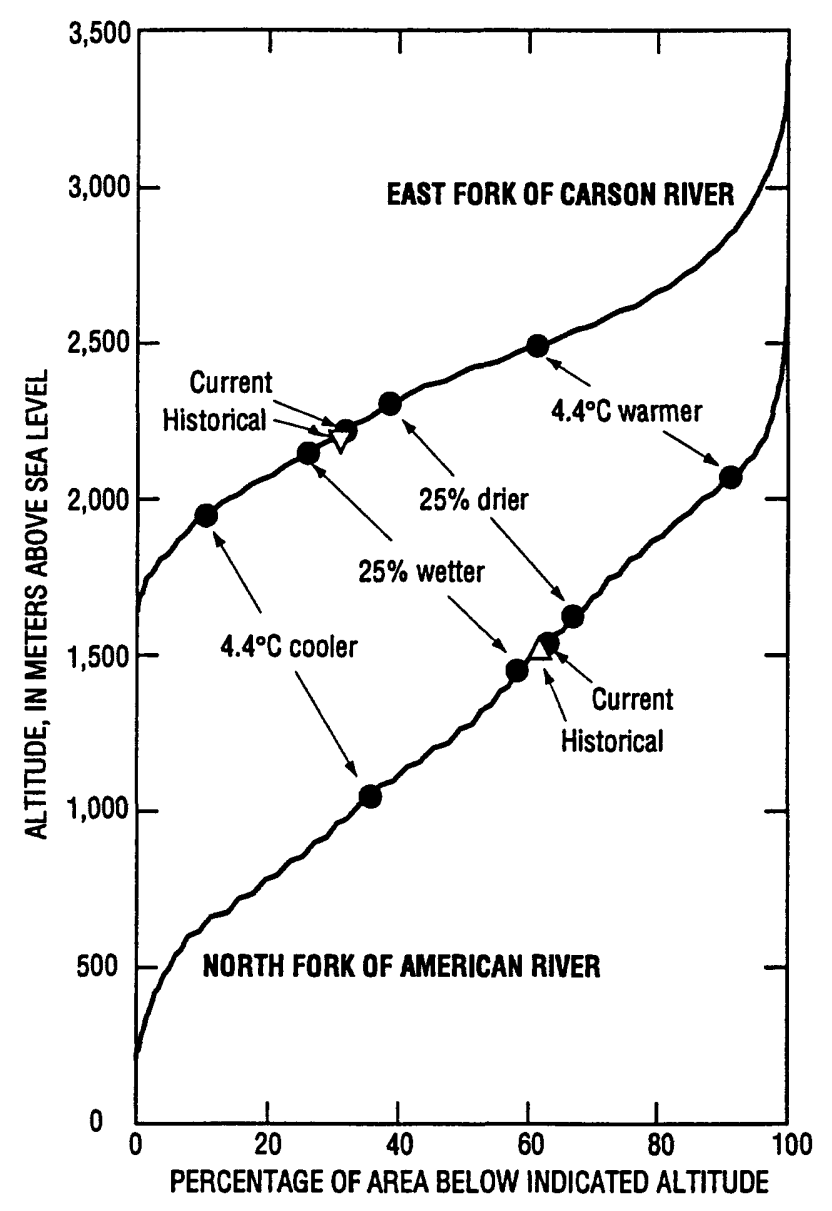

Figure 2. Distribution of altitudes in the North Fork American and East Fork Carson River basins. Dots indicate the simulated percentage of basin that is not covered with snow, on average, during April for selected climate scenarios. Triangles indicate percentage of basin not covered with snow in April in historicalcondition simulations.

snowmelt-derived runoff period from the higher elevations during the late spring and early summer months. Runoff from the Carson basin is mostly late spring snowmelt, whereas the American basin runoff is a mix of runoff from rain and early snowmelt and springtime runoff from later snowmelt in the higher altitudes.

Regionally, the west face of the Sierra is less steep than is the east face, which could influence sensitivities to climate change because changes in snowline altitude would affect larger areas on the regionally less steep side of the range (California Energy Commission, 1991). However, the Carson River is oriented more north-south than the American River (fig. 1) so that the average slope within the Carson River basin actually is less than it would be if it ran due eastward. As a consequence, the percentage of the Carson River basin above a given altitude increases less rapidly than does the percentage of the American River basin above a given altitude (fig. 2). Areas that would be affected by a rising snowline in the Carson River basin would be proportionally more than in the American River basin. Similar differences also characterize most of the other basins on the two sides of the range.

\section{ACKNOWLEDGMENTS}

The authors would like to thank the following agencies for their assistance: U.S. Forest Service, Toyaibe and Tahoe National Forests; National Weather Service in Reno and Sacramento; and U.S. Soil Conservation Service in Davis. Special thanks for advice and contributions are extended to Kelly Redmond of the Western Regional Climate Center, University of Nevada at Reno; Daniel Cayan and Larry Riddle of Scripps Institute of Oceanography; Linda Stannard and Danny Marks, U.S. Geological Survey; Maurice Roos, California Department of Water Resources; Edward Aguado, San Diego State University; and James Risbey, Massachusetts Institute of Technology.

\section{MODEL DESCRIPTION}

This study used the Precipitation-Runoff Modeling System (PRMS), a physically based, deterministic, distributed-parameter model designed to simulate precipitation and snowmelt runoff as well as alpine snowpack accumulation and snowmelt processes (Leavesley and others, 1983). The spatial variability of land characteristics that affect runoff within and from watersheds is accounted for by conceptual disaggregation of the modeled area into parcels known as hydrologic response units (HRU's). A critical assumption is that the hydrologic response to uniformly distributed point precipitation and simulated snowmelt is homogeneous within each HRU. HRU's are characterized by those physiographic properties that determine their hydrologic responses: altitudes, slopes, aspects, vegetation, soils, geology, and climate. An HRU can be a spatially noncontiguous land unit and is not necessarily defined by a single, closed subbasin boundary. PRMS is an accounting model that computes a daily water-energy balance for each HRU. The areaweighted sum of daily hydrologic fluxes from all 


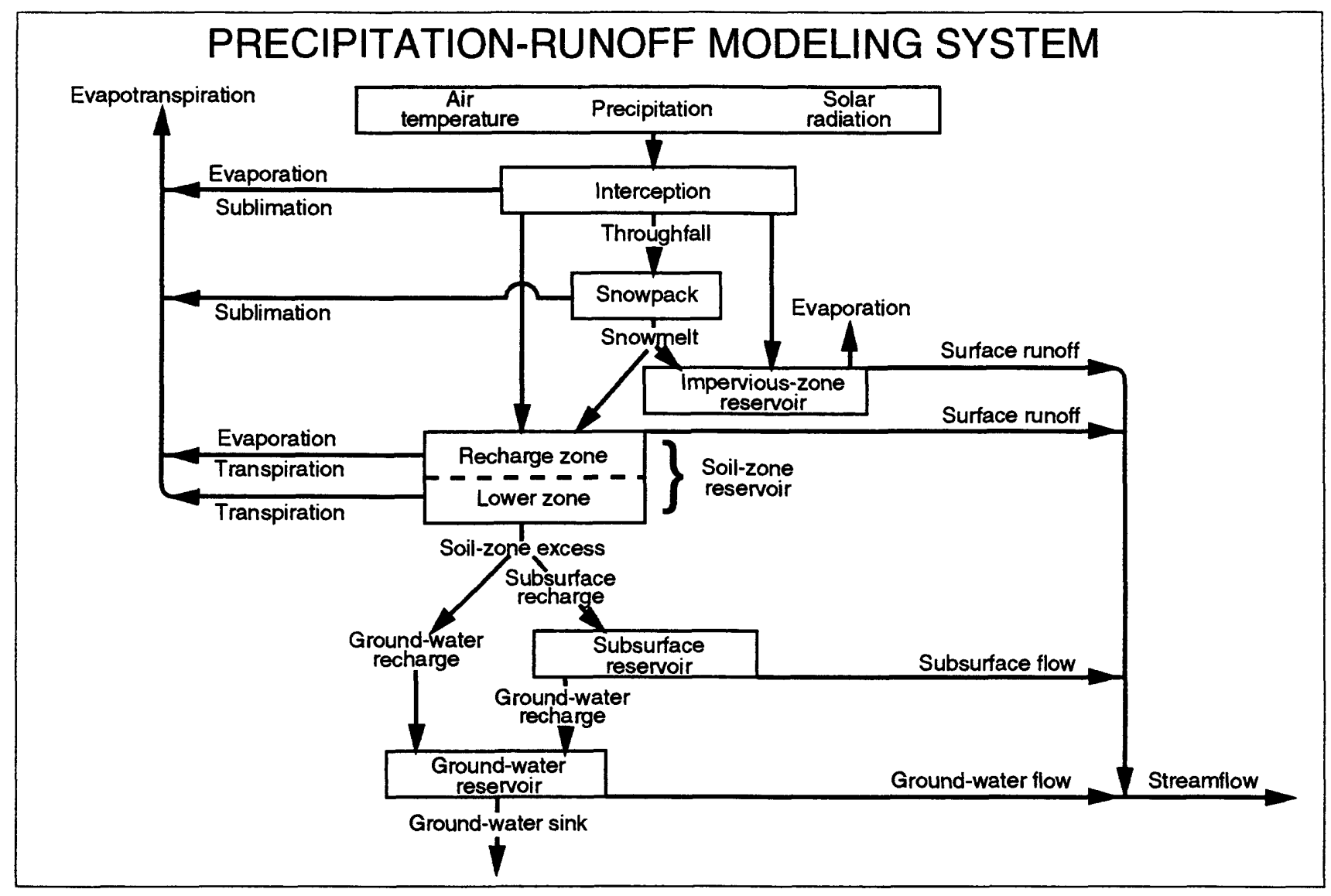

Figure 3. Schematic diagram for Precipitation-Runoff Modeling System. (From Leavesley and others, 1983).

HRU's is the simulated basin response. Changes in moisture within the HRU's are conceptualized as fluxes through and from a series of reservoirs (fig. 3).

PRMS requires input for approximately 50 global parameters and $40 \mathrm{HRU}$-specific parameters. Daily total precipitation, maximum and minimum temperature, and solar radiation drive the models. In this study, solar radiation is estimated from daily air temperatures using a modified degree-day method and is adjusted for slope and aspect (Frank and Lee, 1966; Swift, 1976). Each HRU is indexed to a climate station not necessarily in the HRU. Monthly temperature lapse rates and precipitation correction factors extrapolate measured daily air temperature and precipitation from those stations to individual HRU's, thereby accounting for spatial and altitude differences. Precipitation form (rain, snow, or mixed) is estimated by relations between a specified snow-rain threshold temperature and minimum and maximum temperatures at each HRU.
Potential evapotranspiration (PET) was computed using a version of the Jensen and Haise method (Jensen and Haise, 1963; Jensen and others, 1969) modified to account for forest canopies and changes in elevation and humidity:

$$
P E T=C T S *(T A V F-C T X) * R I N
$$

where

CTS is a monthly air temperature coefficient, $T A V F$ is the daily mean air temperature in the HRU, CTX is an air temperature correction for saturation vapor pressure differences among HRU's, and $R I N \quad$ is the daily solar radiation, expressed as a depth of evaporation potential.

Though simplified, PET computations include saturation vapor pressure estimates that are temperature dependent, thus allowing for adjustments to a broader range of climate conditions. 
PET is first satisfied from canopy-interception storage, then sublimation and impervious surface evaporation. When snow is present and transpiration is not occurring, sublimation is computed as a percentage of the total PET. Remaining PET demand is satisfied from evaporation from the soil surface and soil zone storage after transpiration begins. The transpiration period is dependent on the plant community and altitude zone contained within each HRU. During each year of simulation, a cumulative degree-day index is used to determine the start of transpiration, allowing for earlier and later phenology during cooler and warmer springs or in response to long-term climate changes. PRMS models the soil zone as a twolayer system: a shallow, upper (recharge) zone where losses are from soil evaporation and transpiration, and a deeper, lower zone where the soil moisture depletion is by transpiration and ground-water seepage only. The total soil profile depth for an HRU is defined as the average rooting depth of the dominant vegetation. Actual evapotranspiration (AET) losses from the soil zone are proportional to the remaining PET demand and the ratio of currently available soil moisture to the maximum water-holding capacity of the soil profile and are limited by PET. In this paper, the sum of sublimation, AET, and interception losses is referred to as SET. Soil moisture losses are computed separately for each soil layer. Surface runoff from a snow-free surface is estimated by a nonlinear function of antecedent soil-moisture conditions, daily precipitation amounts, and soil-moisture storage (Dickinson and Whiteley, 1970). For snowmelt, infiltration is a user-defined rate.

The conceptual model for snowmelt follows Obled and Rosse (1977). The snowpack is represented as two layers: an upper boundary layer (3-5 $\mathrm{cm}$ ) and the underlying part of the pack. The snowpack in each HRU is always either in an accumulation or melt phase, depending on the snowpack temperature. When the snowpack is below $0^{\circ} \mathrm{C}$, the pack is in the accumulation stage until a user-defined melt date is reached. The pack enters the melt phase when its temperature has been $0{ }^{\circ} \mathrm{C}$ or above for 5 consecutive days. An energy balance (E) for the surface snowpack layer in each HRU is computed twice daily for 12hour day and night periods:

$$
E=S W N+L W N+C E N+C A L P R
$$

where
$S W N$ is net shortwave radiation,
$L W N$ is net longwave radiation,
$C E N$ is convection-condensation energy, and
$C A L P R$ is the heat content of precipitation.

SWN is estimated as the product of the incoming solar radiation, (1.0 - albedo), and a transmission coefficient for the vegetation canopy. LWN is estimated as the sum of net longwave emissions into the snowpack from open sky and from the plant canopy (assumed to be at the same temperature as the open sky). CEN represents sensible and latent heat losses from the snowpack and is simply the product of a specified monthly coefficient and the mean air temperature. In the Sierra Nevada, these fluxes are typically much smaller than radiative sources of snowpack heat (Aguado, 1985). Albedo is a function of whether the snowpack is in a melt or accumulation phase and the number of days since the most recent snowfall.

Heat transfer between the surface snowpack layer and the remainder of the snowpack occurs by conduction when the temperature of the surface layer is less than $0^{\circ} \mathrm{C}$. When the surface layer temperature is $0^{\circ} \mathrm{C}$ and $\mathrm{E}$ is positive, heat transfer occurs by mass transfer of surface-layer meltwater. When the lower layer is at $0^{\circ} \mathrm{C}$, the snowpack melts while satisfying a free-water holding capacity, which for the present study was set at 5 percent of the snow-water equivalent. The remaining snowmelt is available for infiltration or surface runoff. Snowpack water equivalent is computed daily. Areal snow cover is computed for each HRU using Anderson's (1968) areal depletion curve. Because air temperature and vegetation density are explicitly represented in the energy balances, the PRMS snowpack representation is probably better suited to model climate-change responses than are simpler statistical or regionalized models.

Streamflow, as simulated by PRMS, is a summation of three flow components: surface flow (commonly referred to as overland flow), subsurface flow (or interflow), and shallow ground-water flow. Losses to deep ground-water flow are computed in the model, but in the American and Carson River models are negligible. 


\section{MODEL DEVELOPMENT}

In distributed-parameter precipitation-runoff models, hydrologic processes are parameterized to account for the spatial and temporal variability of basin characteristics. Although partitioning methods differ (see Leavesley, 1973, p. 18-26), the intent of distributed-parameter models is to better conceptualize hydrologic processes, to represent these processes at time and space scales near those in nature, and to reduce model input error, thereby improving overall model performance. Lumped-parameter models depend inherently on assumptions that the modeled systems are sufficiently linear that large-scale average descriptions of vegetation cover, altitude, and climate can be modeled to yield the right "average" streamflow. In reality, runoff generation can be described more accurately in terms of climate-terrain interactions, which require the inclusion of spatial variability. The advantage of distributed-parameter models might not be apparent until the model is confronted with new climatic-cover-terrain conditions not used in the original calibration.

In this study, simulations of the spatial and temporal variability of hydrologic processes in the two basins required (1) characterization of historical climatic and microclimatic variations affecting the basins, (2) development of objective methods for basin characterization and HRU delineation, and (3) estimation of model parameters for the basin and individual HRU's. Basin characterization and parameter estimation were accomplished using a geographic information system (GIS).

\section{CLIMATIC INPUTS}

To ensure that the models were robust to as much climate variability as possible, the models were driven by observed temperature and precipitation rates from nearby climate stations with the longest available periods of record. Meteorologic and streamflow stations used for the two basins are illustrated in figure 1 . Verifiable simulations of the Carson River are limited to $1969-90$ by the period of streamflow record at the outlet gage. Two climate stations near the Carson River basin have daily data for that period: Woodfords (at 1,722 m) and Twin Lakes (at 2,438 m). This period of streamflow record was divided into two 11year periods: a calibration period from water years
1980-90 and a verification period from 1969-79. The American River basin has a more extensive long-term climate record and a longer streamflow record. Four 42-year climate stations were selected: Colfax (734 $\mathrm{m})$, Gold Run (1,012 m), Blue Canyon (1,676 m), and the Central Sierra Snow Lab (2,103 m). The calibration and verification periods for the American River model are from 1969-90 and 1949-68, respectively.

Orographic effects cause significant spatial variations of precipitation in both basins. These effects are more pronounced in the Carson River basin and are reflected in distinct vegetation changes upslope. The precipitation distributed to each HRU in PRMS is equal to the product of a precipitation correction factor $(\mathrm{PCF})$ and the observed precipitation at the climate station indexed to that HRU. For the Carson River model, a simple linear lapse rate was assumed to describe the mean precipitation variations with altitude. This mean lapse rate was estimated for each month based on the elevation and mean precipitation differences at the Woodfords and Twin Lakes sites. Mean HRU precipitation rates were then estimated from the lapse rate and the HRU altitude. Day-to-day precipitation at each $\mathrm{HRU}$ was assumed to be proportional to the deviation of the daily precipitation rates at Woodfords or Twin Lakes from the monthly mean. HRU's above 2,438 m reflect the day-to-day record at Twin Lakes and those below, at Woodfords. Snowcorrection factors were applied to each.

In the American River model, three altitude zones were initially defined to represent orographic effects on precipitation rates. In the 199- to 1,371-m zone, the precipitation distribution was assumed to reflect the 40-year mean orographic lapse rates between the Colfax and Gold Run sites. In contrast, the observed precipitation distribution within the 1,371- to 1,829-m altitude zone suggests a plateau effect (Colton, 1976) and was represented as such in the model. For altitudes greater than $1,829 \mathrm{~m}$, precipitation appears to decrease with an increase in altitude. Colton's (1976) simulated orographic precipitation for a west-east transect along the American River depicts these relationships, suggesting a "rainout" effect. In the calibrated model, rainfall was set equal to the precipitation at the highest climate station (the Central Sierra Snow Lab) regardless of altitude; snowfall was set equal to 95 percent of the precipitation there. 
Temperature lapse rates for the Carson River model were determined from monthly means at the two Carson River climate stations and then were adjusted during calibration; temperature lapse rates for the American River model reflect the differences between monthly means at the lowest (Colfax) and highest (Central Sierra Snow Lab) altitude climate stations.

\section{HYDROLOGIC RESPONSE UNIT DELINEATION USING A GEOGRAPHIC INFORMATION SYSTEM}

Geographic information systems (GIS's) have been used to assist in land characterization and parameter estimation for ground-water models (Kernodle and Phillip, 1987) and surface-water models (Battaglin and others, 1993). Prior to the use of GIS's, basin characterization and HRU delineation was a time-consuming and subjective manual procedure. Hydrographic subbasins were delineated on topographic maps along subbasin ridge lines, and their attributes were estimated from map overlays (Kuhn, 1988). Recently, more time efficient and objective methods for basin characterization using digital data have been developed. Stannard and Leavesley (U.S. Geological Survey, oral commun., 1991) identified subbasins from digital elevation models (DEM's) rather than topographic maps and then defined HRU boundaries as opposing hillslopes within each. Kuhn and Parker (1992) and Leavesley and others (1992) used 5- to 10$\mathrm{km}$ grid cells from an orographic-precipitation model to define HRU's.

A GIS was developed for this study so that detailed descriptions of spatial variations of important basin characteristics could be analyzed objectively and automatically. Data were acquired for the GIS as digitized paper maps, digital raster data (a cellular data structure composed of rows and columns), vector data (points or lines defined by a cartesian coordinate system), and attribute tables (describing digital map feature characteristics) in ASCII format. Source data layers used in basin characterization included raster altitude data from DEM's (U.S. Geological Survey, 1987), from which slope and aspect layers also were derived, and vector land-cover (vegetation) (U.S. Geological Survey, 1986), soil (U.S. Department of Agriculture, 1991), and geologic maps (Carson River basin: Stewart and others, 1982; American River basin: Jennings, 1977).
Using these data, HRU's were delineated by assuming that basin properties can be grouped according to hydrologically significant characteristics even when the corresponding areas do not lie within contiguous areas. This approach allows for a high resolution model that captures the physiographic variability in mountainous basins, without requiring hundreds of distinct HRU's. Because PRMS assumes that instream travel times are less than the daily time step, time lags between noncontiguous parts of an HRU were not modeled and contiguity was not necessary. In PRMS, hydrologic fluxes are assumed to be uniform over all component parts of an HRU and are scaled by its total area. To delineate these noncontiguous HRU's, a methodology was developed to delineate hydrologically homogeneous, spatially noncontiguous land units for use as HRU's according to the following criteria: (1) source data layers and groupings of classed data were selected for their hydrologic significance and had resolutions appropriate to the basin's natural spatial variability, (2) HRU definitions were not limited by contiguity, (3) the technique for delineating HRU's was flexible to accommodate different classification criteria, and (4) the technique was objective and reproducible. Limitations of this methodology are addressed later in this report.

Figure 4 illustrates the resulting methodology. In step 1 , source data were reformatted to provide consistent GIS coverages as raster cells on a $100-\mathrm{m}$ grid. Slope and aspect layers were derived from the altitude layer (fig. 4, step 2). Data in the source layers were lumped into discrete categories according to hydrologic and climatic considerations (fig. 4, step 3). The categories used in the Carson model are given in table 1; similar categories were used in the American model. Altitude zones were chosen to distinguish observable differences in temperature and precipitation within the basin. Slope categories were chosen to distinguish geomorphic landforms, and aspect categories were chosen to span solar radiation estimates from Liebermann (1991). Land-cover categories describe generalized vegetation classes within the basins. Soils were regrouped according to generalized soil textures. The sixth data layer, geology, was not used in the HRU delineation process, but was used later in step 7 to assign each HRU to one of two subsurface reservoirs in the basin.

A spatial pattern-recognition technique similar to standard image classification (Lillesand and Kiefer, 


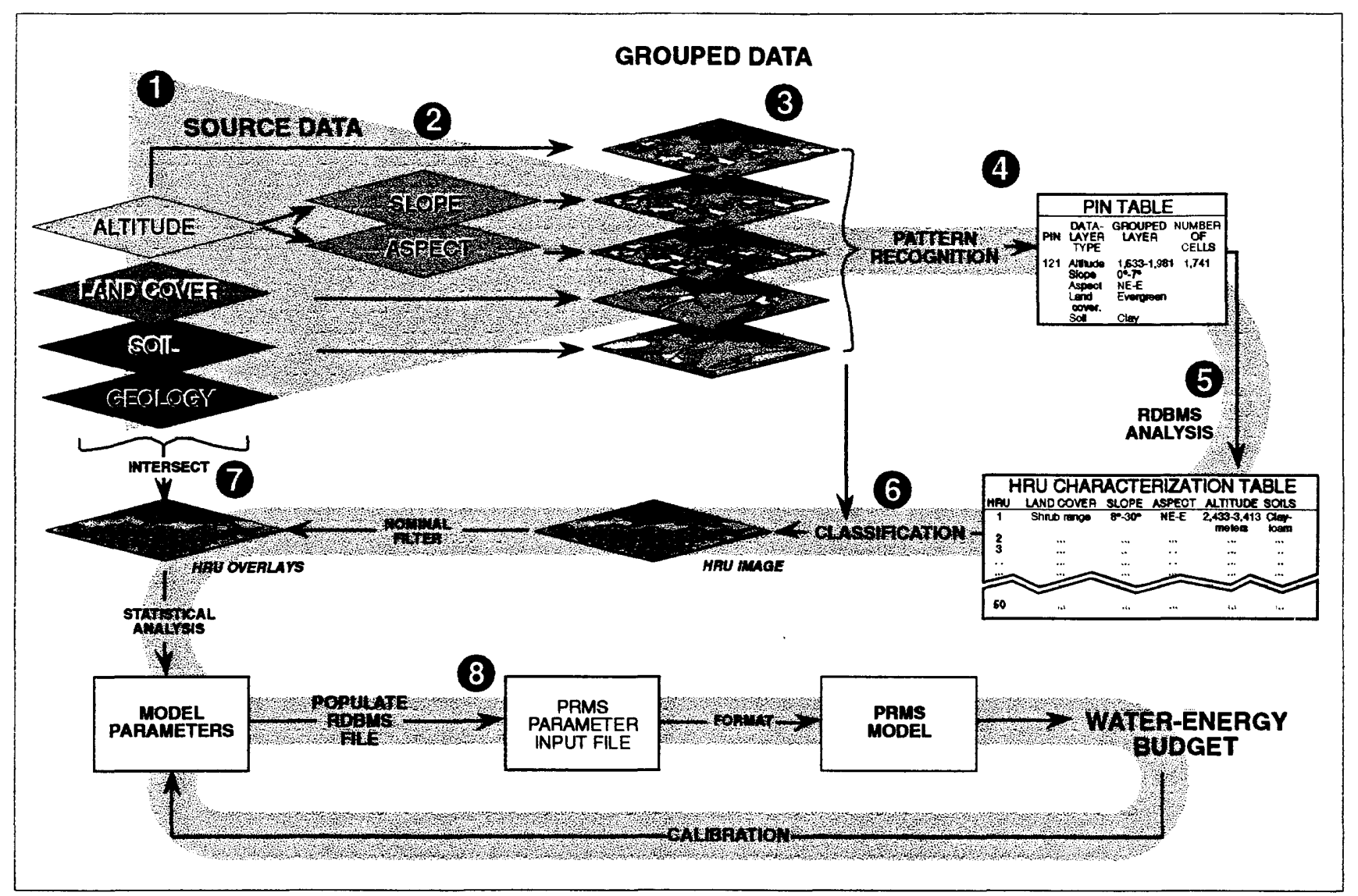

Figure 4. Steps in basin characterization and hydrologic response unit (HRU) delineation. Altitude in meters. PIN, pattern-identification number; PRMS, Precipitation-Runoff Modeling System; RDBMS, Relational Data-Base Management System.

1987) was then applied to the five grouped data layers (fig. 4, step 4). Each 100 - by $100-\mathrm{m}$ area in the basin was characterized by its own combination of the five data layers, and each pattern realized was given a pattern-identification number (PIN). A relational database management system (RDBMS) (fig. 4, step 5) was used to analyze the distribution and frequency of PIN's and to reassign hydrologically similar PIN's to common subsets. For example, several PIN's, characterized by steep slopes, similar aspect, and similar vegetation cover, but differing in soil type, would be regrouped into a single, slightly more general subset. Such subsetting would be justified because soils on steep slopes commonly are shallow and poorly formed, and thus the role of the soil-zone reservoir is reduced. Then, cells were assigned to HRU's on the basis of the PIN subsets (fig. 4, step 6). The resulting HRU layer was nominally filtered, a raster-processing technique that removes isolated cells or small clusters that are different from their surroundings. An example of the resulting overlay is shown in figure 5 , which shows the noncontiguous nature of the HRU's defined by this process.

Minimum HRU areas for the Carson River and American River basins were 312 ha and 383 ha, respectively. Individual HRU's range from 0.5 to approximately 6 percent of the Carson River basin and from 0.3 to approximately 12 percent of the American River basin. For the Carson River, the dominant HRU is an evergreen forest, high altitude land unit on moderate slopes with a northeasterly aspect. Its gravelly sand soil type reflects the dominant granodiorite bedrock material. The dominant American River HRU is an evergreen forest, middle altitude land unit on gentle slopes with a southerly aspect. Its clay soil type reflects a dominantly volcanic to metasedimentary bedrock geology.

Finally, for each HRU, the frequency distributions of characteristics (from the original data sources) of all cells within the HRU were plotted (fig. 4, step 7). These distributions were used as a basis for estimating HRU-dependent parameters to reduce errors 
Table 1. Grouped GIS data for the East Fork Carson River basin

[HRU, hydrologic response unit; --, not applicable]

\begin{tabular}{|c|c|c|c|}
\hline \multirow{2}{*}{ Type of data layer } & \multirow{2}{*}{ Source categories } & \multicolumn{2}{|c|}{ Grouped HRU-characterization categories } \\
\hline & & Number & Description \\
\hline Altitude & -- & 3 & $\begin{array}{l}1,683-1,981 \text { meters } \\
1,981-2,438 \text { meters } \\
2,438-3,413 \text { meters }\end{array}$ \\
\hline Slope & 68 degree classes & 4 & $\begin{array}{c}0^{\circ}-7^{\circ} \\
8^{\circ}-30^{\circ} \\
31^{\circ}-45^{\circ} \\
>45^{\circ}\end{array}$ \\
\hline Aspect & 9 compass points (plus level land) & 6 & $\begin{array}{c}\text { North facing } \\
\text { Northeast and east } \\
\text { Southeast, southwest, } \\
\text { south, and level } \\
\text { Northwest and west }\end{array}$ \\
\hline Land cover & 9 type classes & 6 & $\begin{array}{c}\text { Evergreen forest } \\
\text { Mixed forest } \\
\text { Deciduous forest } \\
\text { Shrub rangeland } \\
\text { Herbaceous rangeland } \\
\text { Shrub tundra }\end{array}$ \\
\hline Soil & 35 type classes & 4 & $\begin{array}{c}\text { Clay } \\
\text { Clay loam } \\
\text { Gravelly sand } \\
\text { Sandy loam }\end{array}$ \\
\hline Geology & 23 type classes & 5 & $\begin{array}{l}\text { Basin-fill sediments } \\
\text { Metasedimentary rocks } \\
\text { Silicic volcanic rocks } \\
\text { Felsic intrusive rocks } \\
\text { Mafic intrusive rocks }\end{array}$ \\
\hline
\end{tabular}

attributable to the spatial lumping of parameters and to use the 'distributed' nature of PRMS to its fullest. To illustrate, in a particular HRU, soil texture might be described as clay among the lumped categories when, in reality, the soil was varied. The soil data layer containing the original 32 soil classes would be intersected with the HRU layer. Then, the actual range of soil classes within the HRU provided a basis for selecting infiltration rates and water-holding capacities. In step 8, the RDBMS was used to populate an HRU spreadsheet and PRMS input files. Storing HRU parameters in the spreadsheet allowed easy adjustments during calibration.

\section{MODEL CALIBRATION AND VERIFICATION}

\section{CALIBRATION}

The objectives of model calibration were (1) satisfactory simulations of historical streamflow and
(2) models suitable for simulating long-term climatechange responses. Initial parameter estimates were obtained from previous reports and models or from the GIS described in the preceding section. During calibration, parameters were modified to improve the match between observed and simulated streamflows at the two gages while maintaining realistic values of all parameters. The objective function used to measure calibration success was the sums of the absolute values of differences between predicted and observed daily flows.

Sensitivity analyses during calibration helped determine whether remaining parameter uncertainties resulted in unacceptable prediction uncertainties. The Rosenbrock optimization algorithm (Rosenbrock, 1960; Leavesley and others, 1983) and trial-and-error were used to select parameters for adjustment. Parameters were selected for calibration according to whether they affected long-term volume (monthly and annual) response, short-term runoff (with particular 


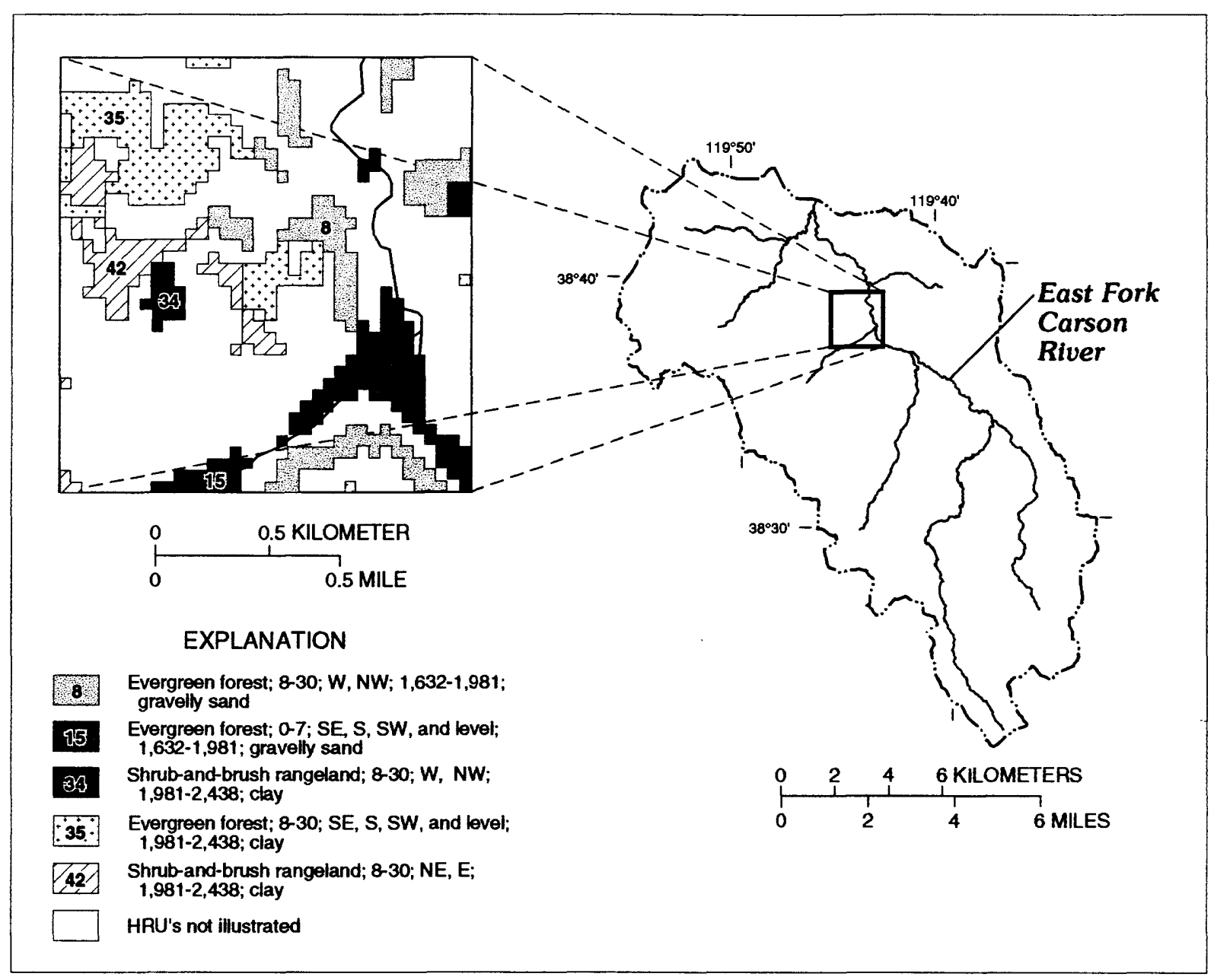

Figure 5. Subset of hydrologic response units (HRU) for East Fork Carson River basin. Explanation of units listed in order of land cover, slope (in degrees), aspect (compass facings), altitude (in meters), and soil.

attention to timing), or storage volumes for the model reservoirs (canopy interception, snowpack, soil, and subsurface zones). In the Carson River model, uncertainty in the following parameters was most likely to induce large prediction errors (listed in decreasing importance): the snow threshold temperature that determines precipitation form, precipitation correction factor for snow, monthly evapotranspiration coefficients for the Jensen-Haise PET computation, winter canopy transmission coefficient, and monthly temperature lapse rates. Lapse rates for maximum and minimum temperatures were equally sensitive. Parameters most sensitive in the American River model were snow threshold temperature, precipitation correction factors for rain, minimum temperature lapse rates, and the canopy transmission coefficient.

The spatial distributions of precipitation and temperature affect both streamflow volumes and timing. The calibrated lapse rates averaged 8.5 and 7.4 ${ }^{\circ} \mathrm{C} / \mathrm{km}$ for the Carson and American River basins, respectively. These lapse rates are higher than the standard lapse of $6^{\circ} \mathrm{C} / \mathrm{km}$, but variations in lapse rates can be large depending on air-mass types, climatic region, inversion strengths, and gravity-drainage effects (Barry, 1981). Simulated streamflow timing was also sensitive to the monthly PET coefficients. Final PET values were adjusted to reflect regional PET estimates that mostly were derived from pan-evaporation data. Increasing the lapse rates for the Carson model while maintaining reasonable PET rates and a snow threshold temperature of $0^{\circ} \mathrm{C}$ significantly improved streamflow timing. In the American River basin, the snow threshold temperature varies considerably during the winter precipitation season, and rain on snow is frequent. Winter storm records at Central Sierra Snow $\operatorname{Lab}(2,100 \mathrm{~m})$ for water years $1968-76$ and 1982-88 indicate snow formation at mean temperatures between -10 and $7^{\circ} \mathrm{C}$, based on decreases and increases in snow-water equivalent following precipitation. As much as 50 percent of winter streamflow timing error was corrected by increasing the snow threshold tem- 
Table 2. Annual statistics for the East Fork Carson River streamflow

[Mean error, $100 \times\left(\right.$ simulated-observed)/observed/(number of years); $\mathrm{m}^{3} / \mathrm{s}$, cubic meter per second. $\mathrm{R}^{2}$, coefficient of determination for monthly runoff]

\begin{tabular}{|c|c|c|c|c|}
\hline & \multicolumn{2}{|c|}{ Calibration period (1980-90) } & \multicolumn{2}{|c|}{ Verification period (1969-79) } \\
\hline & Observed & Simulated & Observed & Simulated \\
\hline Mean $\left(\right.$ in $\left.\mathrm{m}^{3} / \mathrm{s}\right) \ldots \ldots \ldots \ldots \ldots \ldots$ & 10.7 & 11.1 & 9.7 & 10.0 \\
\hline Standard deviation $\left(\right.$ in $\left.\mathrm{m}^{3} / \mathrm{s}\right) \ldots \ldots \ldots$ & 6.6 & 6.3 & 4.0 & 3.7 \\
\hline Coefficient of variation $\ldots \ldots \ldots \ldots \ldots$ & 0.61 & 0.56 & 0.41 & 0.37 \\
\hline & \multicolumn{2}{|c|}{0.88} & \multicolumn{2}{|c|}{0.80} \\
\hline Mean error $\ldots \ldots \ldots \ldots \ldots$ & \multicolumn{2}{|c|}{+10} & \multicolumn{2}{|c|}{+8} \\
\hline Root mean square error $\left(\right.$ in $\left.\mathrm{m}^{3} / \mathrm{s}\right) \ldots \ldots \ldots$ & \multicolumn{2}{|c|}{2.3} & \multicolumn{2}{|c|}{1.7} \\
\hline Minimum residual (in $\left.\mathrm{m}^{3} / \mathrm{s}\right) \ldots \ldots \ldots \ldots$ & \multicolumn{2}{|c|}{-0.3} & \multicolumn{2}{|c|}{-3.2} \\
\hline Maximum residual $\left(\right.$ in $\left.\mathrm{m}^{3} / \mathrm{s}\right) \ldots \ldots \ldots$ & \multicolumn{2}{|c|}{4.9} & \multicolumn{2}{|c|}{2.6} \\
\hline Durbin-Watson test statistic . . . . . . . . . & \multicolumn{2}{|c|}{0.95} & \multicolumn{2}{|c|}{2.37} \\
\hline
\end{tabular}

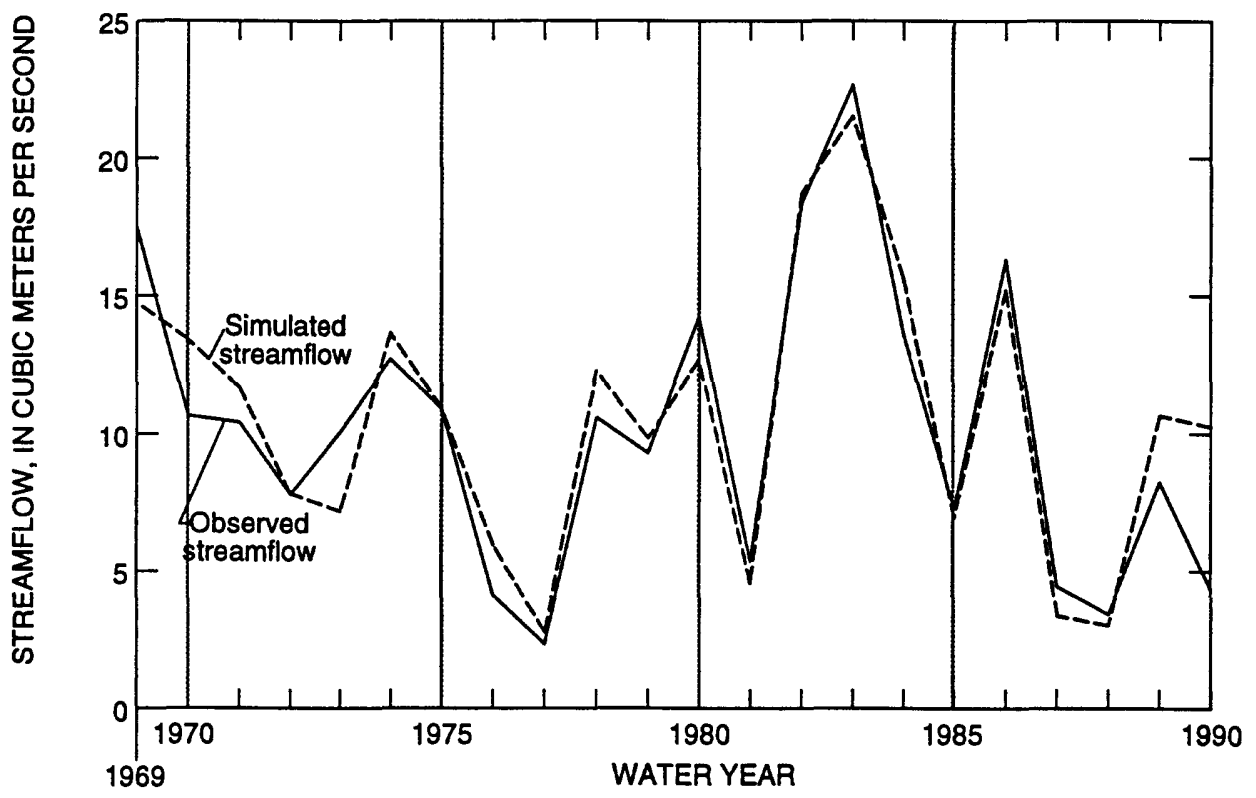

Figure 6. Observed and simulated annual mean flows for East Fork Carson River for water years 1969-90.

perature to $4.0^{\circ} \mathrm{C}$ while maintaining a mean temperature lapse rate of $1.4^{\circ} \mathrm{C} / \mathrm{km}$ above the standard.

\section{ERROR ANALYSIS}

Calibration results are analyzed here in a framework similar to regression analysis (Troutman, 1985). Although simulated streamflow is a nonlinear function of the model inputs, in the absence of systematic errors, distributions of the model errors should have several properties demanded of residuals from linear regression: calibration errors ideally should be small, additive, and not functions of model inputs or parameter estimates. Because the models are intended for assessments of climate-change sensitivities, their robustness is of concern. No single calibration of the PRMS model will simulate all flow regimes with the same level of error, and indeed, in this study, the focus of calibration was mostly on average to wet years.

Annual summary statistics for the Carson River model are presented in table 2 and illustrated in figure 6. The average difference between observed and sim- 


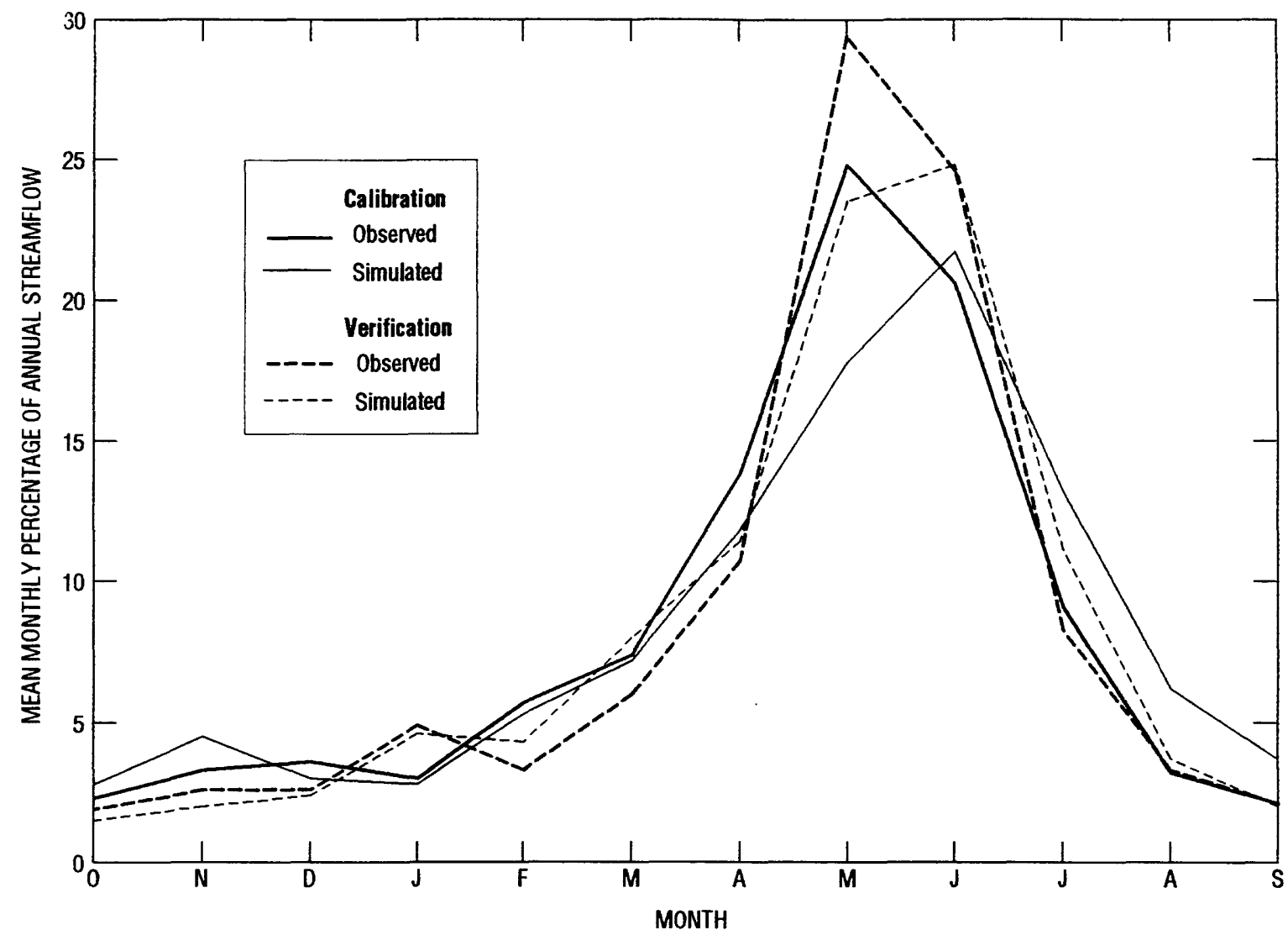

Figure 7. Mean monthly streamflow for East Fork Carson River basin as percentage of annual streamflow for the calibration (1980-90) and verification (1969-79) periods.

ulated annual streamflow is +10 percent for the calibration period $(1980-90)$ and +8 percent for the verification period (1969-79). Annual error ranges from -29 to +137 percent. Coefficients of determination $\left(R^{2}\right)$ in table 2 indicate that 88 percent and 80 percent of the variance is accounted for by the model for the calibration and verification periods, respectively. There is a tendency toward undersimulating flow during abnormally wet years (by 13 percent on average) and oversimulating flow during dry years (30 percent on average). Residual error plots for mean annual flows (not shown) reflect near-homoscedastic conditions (constant variance) for both calibration and verification periods. A few years (water years 1970, 1973, and 1990) appear as outlier points and thus tend to skew the otherwise random distribution of annual errors. The time series of annual flow residuals (not shown) suggests a possible serial correlation between the residuals, which was tested by calculating the nonparametric Durbin-Watson statistic. An absence of serial correlation is indicated by statistic values of 2 , with negative correlations above that and positive below (Ott, 1988). Thus, the results in table 2 indicate a positive serial correlation in the calibration period and a slight negative correlation in the verification period. These serial correlations can result from either systematic errors in the model (Helsel and Hirsch, 1992) or serial correlations in the climatic conditions driving the model.

Mean monthly flows (as percentage of annual) for the Carson model are illustrated in figure 7. Relative monthly error and percentage of annual streamflow error are shown in table 3. Simulated streamflow timing reflects a bias toward undersimulating the peak streamflow months, April and May, by an average of 20 percent of the observed flow during the calibration period and 14 percent of the observed flow during the verification period. This results in the oversimulation of June through September streamflow (fig. 7) by an average of 54 percent for the calibration period and 14 percent for the verification period. However, these summer errors are small in magnitude because streamflow in these months is mostly baseflow (only 3 percent of the total annual flow). 
Table 3. Observed and simulated monthly runoff for the East Fork Carson River basin, as a percentage of annual streamflow

[Error $=$ simulated-observed; Rel. error $=$ relative error in cubic meters per second; $\mathrm{R}^{2}=$ coefficient of determination for monthly runoff]

\begin{tabular}{|c|c|c|c|c|c|c|c|c|c|c|}
\hline \multirow{3}{*}{ Month } & \multicolumn{5}{|c|}{ Calibration period (1980-90) } & \multicolumn{5}{|c|}{ Verification period (1969-79) } \\
\hline & \multicolumn{2}{|c|}{ Flow (percent) } & \multirow{2}{*}{ Error } & \multirow{2}{*}{$\begin{array}{l}\text { Rel. } \\
\text { error }\end{array}$} & \multirow{2}{*}{$\mathbf{R}^{2}$} & \multicolumn{2}{|c|}{ Flow (percent) } & \multirow{2}{*}{ Error } & \multirow{2}{*}{$\begin{array}{l}\text { Rel. } \\
\text { error }\end{array}$} & \multirow{2}{*}{$\mathbf{R}^{2}$} \\
\hline & Observed & Simulated & & & & Observed & Simulated & & & \\
\hline October & 2.3 & 2.8 & 0.5 & 24.0 & 0.62 & 1.9 & 1.5 & -0.4 & -17.6 & 0.64 \\
\hline November & 3.3 & 4.5 & 1.2 & 40.0 & .67 & 2.6 & 2.0 & -.6 & 10.6 & .88 \\
\hline December & 3.6 & 3.0 & -.6 & -15.0 & .92 & 2.6 & 2.4 & -.2 & -7.0 & .70 \\
\hline January & 3.0 & 2.8 & -.2 & -24.0 & .69 & 4.9 & 4.6 & -.3 & -5.8 & .85 \\
\hline February & 5.7 & 5.3 & -.4 & -4.0 & .91 & 3.3 & 4.3 & 1.0 & 33.2 & .46 \\
\hline March & 7.4 & 7.2 & -.2 & -1.0 & .70 & 6.0 & 8.0 & 2.0 & 38.1 & .57 \\
\hline April & 13.8 & 11.8 & -2.0 & -13.0 & .80 & 10.7 & 11.4 & .7 & 10.4 & .84 \\
\hline May & 24.8 & 17.8 & -7.0 & -26.0 & .94 & 29.4 & 23.5 & -5.9 & -17.4 & .90 \\
\hline June & 20.6 & 21.7 & 1.1 & 8.0 & .93 & 24.6 & 24.8 & .2 & 4.4 & .72 \\
\hline July & 9.1 & 13.2 & 4.8 & 49.0 & .40 & 8.3 & 11.1 & 2.8 & 37.4 & .61 \\
\hline August & 3.2 & 6.2 & 3.0 & 89.0 & .57 & 3.3 & 3.7 & .4 & 18.1 & .65 \\
\hline September & 2.1 & 3.7 & 1.6 & 72.0 & .72 & 2.1 & 2.0 & -.1 & -3.3 & .66 \\
\hline
\end{tabular}

The American model was calibrated on streamflows during the period $1969-90$ and verified on the period 1949-68. Annual summary statistics are provided in table 4 and illustrated in figure 8 . Model bias in the annual flow is +15 percent of the observed flow for the calibration period and +14 percent for the verification period. Annual error for the 42-year modeling period ranges from -11 to +72 percent. $R^{2}$ values are 0.96 for the calibration period and 0.97 for the verification period. As with the Carson model, the American model tends to overestimate flow in dry years. No bias is apparent during wet years. As with the Carson model, annual streamflow residual plots (not shown) indicate a random pattern, suggesting the lack of systematic modeling error. The Durbin-Watson statistics (table 4) for serial correlation on the American River annual flows indicate a slight positive correlation for the calibration period and essentially none for the verification period. Lumping the calibration and verification periods for the Carson River model yields an overall Durbin-Watson statistic for the 1969-90 period of 1.7 , which is the same as the statistic for the American River in the same period. This similarity suggests that the serial correlations are externally forced on the models, presumably by correlated climate forcings.

The monthly flows (as percentages of annual) for the American River are illustrated in figure 9. Relative monthly error and percent of annual streamflow error are shown in table 5. The model had a tendency to overestimate streamflow during the late fall and early winter months (November through January) during the calibration period, on average by 27 percent of the observed flows. The model underestimated streamflow during spring months (March through May) by 10 percent for the calibration period on average and 27 percent for the verification period. This bias may be explained in part by the sensitivity of the American River basin to daily temperature as distributed by the temperature lapse rates. Mean monthly error plots for the warm years and cool years (not shown) suggest that the warm years contributed most to the overall average late fall to early winter excesses in simulated streamflow. April and May streamflow were more subject to model error during cool years. Overall, it appears the American River model may act as if too cool in cool years and too warm in warm years. 


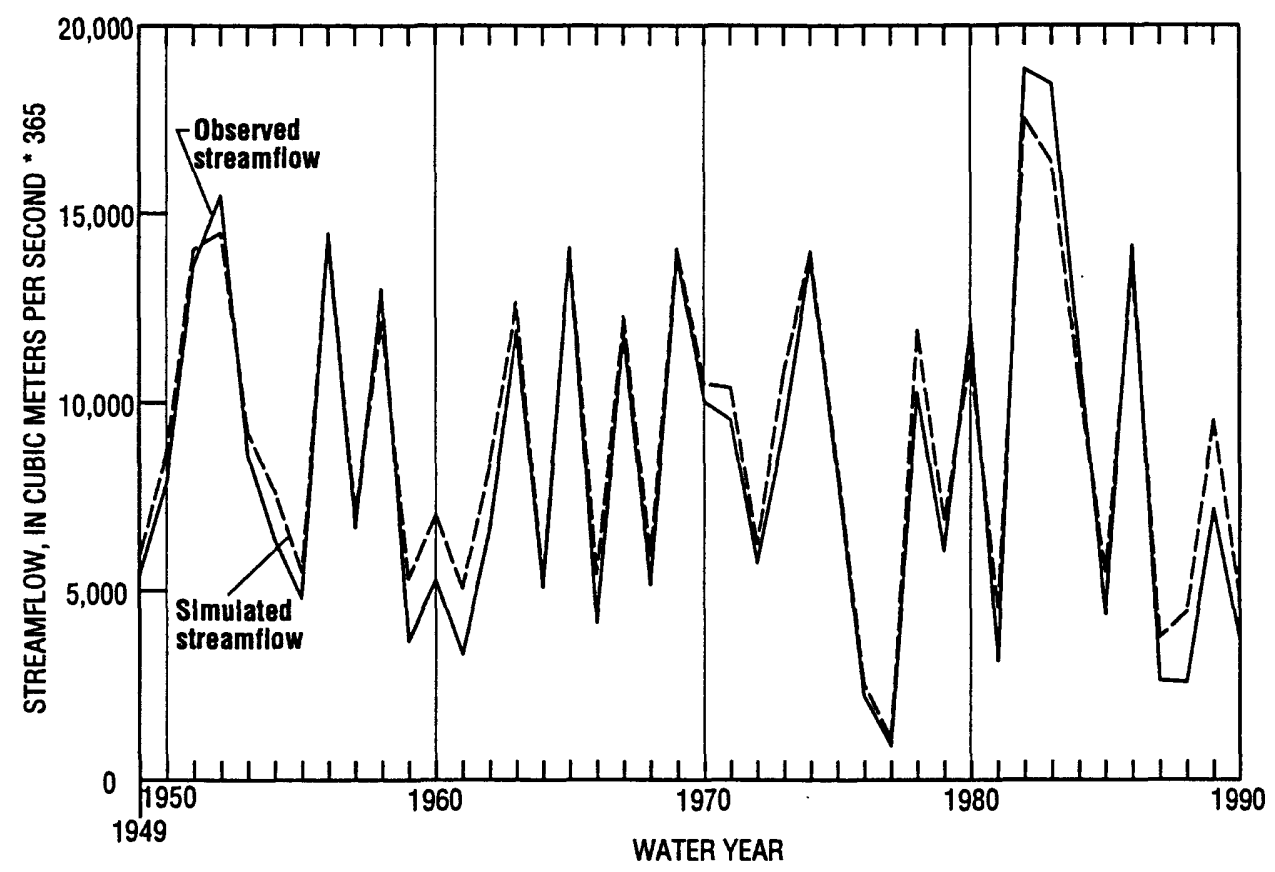

Figure 8. Observed and simulated annual mean flows for North Fork American River for water years $1949-90$.

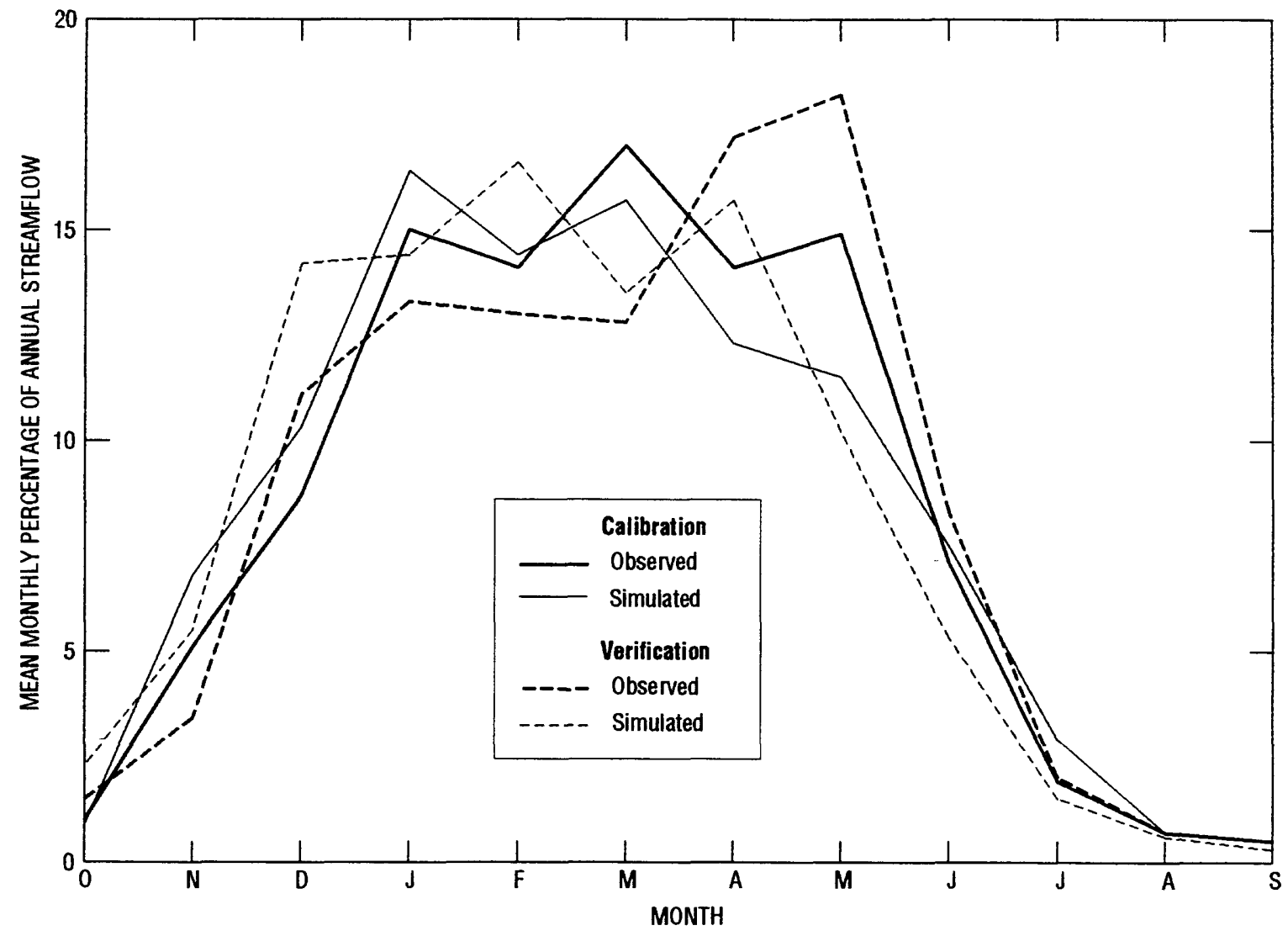

Figure 9. Mean monthly streamflow for North Fork American River basin as percentage of annual streamflow for the calibration (1969-90) and verification (1949-68) periods. 
Table 4. Annual summary statistics for the North Fork American River streamflow

[Mean error, $100 \times$ (simulated-observed)/observed/(number of years); $\mathrm{m}^{3} / \mathrm{s}$, cubic meter per second. $\mathrm{R}^{2}$, coefficient of determination for monthly runoff]

\begin{tabular}{|c|c|c|c|c|}
\hline & \multicolumn{2}{|c|}{ Calibration period (1969-90) } & \multicolumn{2}{|c|}{ Verification period (1949-68) } \\
\hline & Observed & Simulated & Observed & Simulated \\
\hline Mean (in $\mathrm{m}^{3} / \mathrm{s}$ ) . & 23.4 & 24.7 & 22.9 & 24.7 \\
\hline Standard deviation $\left(\right.$ in $\left.\mathrm{m}^{3} / \mathrm{s}\right) \ldots \ldots \ldots \ldots$ & 14.0 & 12.2 & 10.9 & 95.3 \\
\hline Coefficient of variation . . . . . . . . & 0.60 & 0.49 & 0.48 & 0.39 \\
\hline 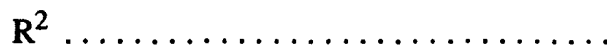 & \multicolumn{2}{|c|}{0.96} & \multicolumn{2}{|c|}{0.97} \\
\hline Mean error..$\ldots \ldots \ldots \ldots \ldots \ldots \ldots$ & \multicolumn{2}{|c|}{+15} & \multicolumn{2}{|c|}{+14} \\
\hline Root mean square error $\left(\right.$ in $\left.\mathrm{m}^{3} / \mathrm{s}\right) \ldots \ldots$ & \multicolumn{2}{|c|}{2.3} & \multicolumn{2}{|c|}{1.5} \\
\hline Minimum residual (in $\mathrm{m}^{3} / \mathrm{s}$ ) . . . . . & \multicolumn{2}{|c|}{0.04} & \multicolumn{2}{|c|}{-2.6} \\
\hline Maximum residual (in $\left.\mathrm{m}^{3} / \mathrm{s}\right) \ldots \ldots \ldots$ & \multicolumn{2}{|c|}{4.6} & \multicolumn{2}{|c|}{2.3} \\
\hline Durbin-Watson test statistic $\ldots \ldots \ldots \ldots$ & \multicolumn{2}{|c|}{1.72} & \multicolumn{2}{|c|}{1.96} \\
\hline
\end{tabular}

Table 5. Observed and simulated monthly runoff for the North Fork American River basin, as a percentage of annual streamflow

[Error, simulated-observed; Relative error, relative error in cubic meter per second; $\mathbf{R}^{2}$, coefficient of determination for monthly runoff]

\begin{tabular}{|c|c|c|c|c|c|c|c|c|c|c|}
\hline \multirow{3}{*}{ Month } & \multicolumn{5}{|c|}{ Calibration period (1969-90) } & \multicolumn{5}{|c|}{ Verification period (1949-68) } \\
\hline & \multicolumn{2}{|c|}{ Flow (percent) } & \multirow{2}{*}{ Error } & \multirow{2}{*}{$\begin{array}{l}\text { Relative } \\
\text { error }\end{array}$} & \multirow{2}{*}{$\mathbf{R}^{2}$} & \multicolumn{2}{|c|}{ Flow (percent) } & \multirow{2}{*}{ Error } & \multirow{2}{*}{$\begin{array}{l}\text { Relative } \\
\text { error }\end{array}$} & \multirow{2}{*}{$\mathbf{R}^{2}$} \\
\hline & Observed & Simulated & & & & Observed & Simulated & & & \\
\hline October & 1.0 & 0.9 & -0.5 & -5.0 & 0.93 & 1.5 & 2.3 & 0.8 & 65.0 & 0.99 \\
\hline November & 5.1 & 6.8 & 1.7 & 42.0 & .93 & 3.4 & 5.5 & 2.1 & 72.0 & .98 \\
\hline December & 8.7 & 10.3 & 1.6 & 25.0 & .81 & 11.1 & 14.2 & 3.1 & 38.0 & .96 \\
\hline January & 15.0 & 16.4 & 1.4 & 15.0 & .88 & 13.3 & 14.4 & 1.1 & 37.0 & .66 \\
\hline February & 14.1 & 14.4 & .3 & 8.0 & .88 & 13.0 & 16.6 & 3.6 & 38.0 & .74 \\
\hline March & 17.0 & 15.7 & -1.3 & -2.0 & .74 & 12.8 & 13.5 & .7 & 13.0 & .67 \\
\hline April & 14.1 & 12.3 & -1.8 & -8.0 & .88 & 17.2 & 15.7 & -1.5 & -1.0 & .95 \\
\hline May & 14.9 & 11.5 & -3.4 & -19.0 & .82 & 18.2 & 10.2 & -8.0 & -39.0 & .77 \\
\hline June & 7.0 & 7.5 & .4 & 11.0 & .78 & 8.3 & 5.3 & -3.0 & -31.0 & .59 \\
\hline July & 1.9 & 2.9 & 1.0 & 59.0 & .82 & 2.0 & 1.5 & -.5 & -19.0 & .64 \\
\hline August & .7 & .7 & 0 & 15.0 & .88 & .7 & .6 & -.1 & -11.0 & .46 \\
\hline September & .5 & .5 & 0 & 9.0 & .77 & .5 & .3 & -.2 & -39.0 & .27 \\
\hline
\end{tabular}

Because the models were developed for use in assessing climate-change sensitivities, their robustness is of concern. The summary statistics presented above suggest that the model can reproduce average streamflows from the last 22 to 42 years. However, model performance under extreme conditions in individual years should also be considered. For example, figure 10 illustrates daily observed and simulated streamflow for water years 1977 (warm-dry) and 1983 (cool-wet). Note that the $y$-axes have been scaled to the individual 

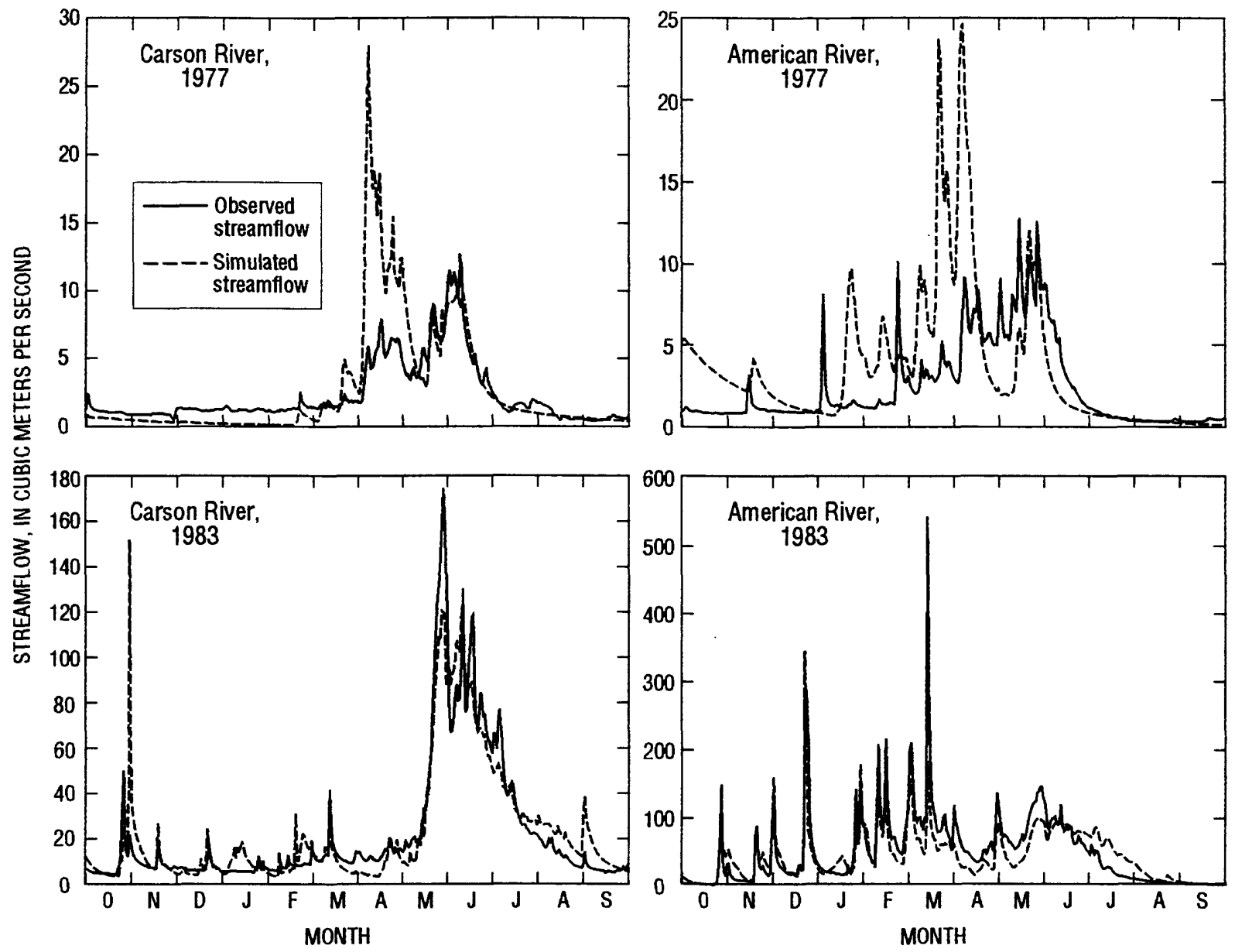

Figure 10. Hydrographs of daily mean flows for East Fork Carson and North Fork American River basins for water years 1977 and 1983.

years. Streamflow timing was well reproduced in the four hydrographs, although fall baseflow in the Carson basin for dry years (represented by the 1977 hydrograph) is underestimated. The American model underestimated streamflow in mid-spring months, perhaps because it was being represented as too warm during fall and winter. Flow-duration plots of daily streamflow in figure 11 show that both models perform best during greater than median flows. Although low flows are overestimated, flows equal to or greater than the median flow were simulated to within 15 percent by the Carson model and to within 20 percent by the American model.

\section{SIMULATED WATER BUDGETS}

The "historical" water balances of the two calibrated models are different in terms of seasonal streamflow, SET, runoff contributions, and snowmelt patterns. Monthly water-budget components (precipitation, PET, SET, and snowmelt) for the Carson and American River basins are illustrated in figure 12 for the period from 1969 to 1990 when simulation periods for both basins are concurrent. At the regional scale, hydrologic differences between the Carson and American Rivers are more the result of their different altitudes (and consequently their temperature differences) than of climatic differences characteristic of windward and leeward basins. The Carson is a high altitude basin with 88 percent of the basin at altitudes greater than $1,980 \mathrm{~m}$, whereas 85 percent of the American River basin lies below $1,980 \mathrm{~m}$. As noted earlier, 88 percent of the Carson River basin is above the current snowline in contrast to only 40 percent of the American River basin. Should the snowline elevations rise or fall in response to climate change, snowpacks in both basins would be affected, but differences will 


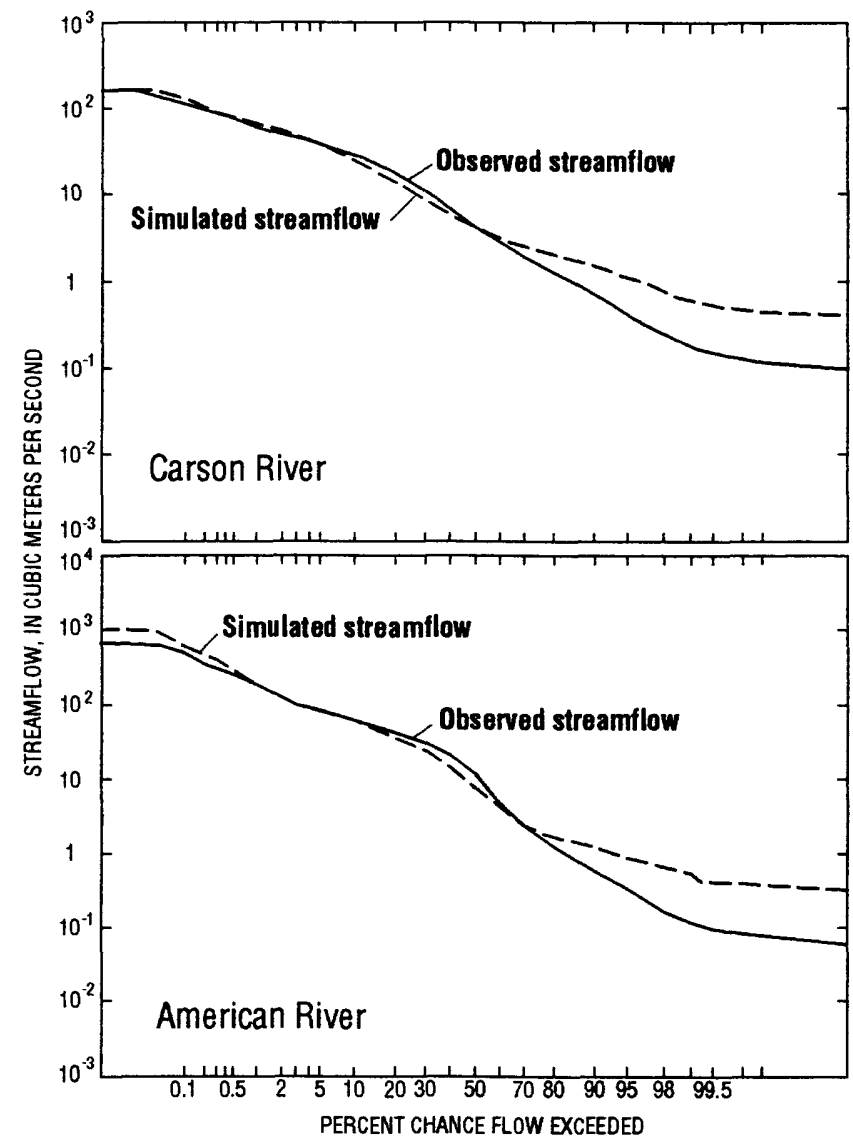

Figure 11. Flow-duration curves for observed and simulated daily streamflow for $1969-90$ for East Fork Carson and North Fork American Rivers.

Table 6. Simulated annual water budget for $1969-90$ for the Carson and American River models

[mm, millimeter; PET, potential evapotranspiration; SET, sum of simulation, actual evapotranspiration, and interception losses]

\begin{tabular}{|c|c|c|c|c|}
\hline \multirow[b]{2}{*}{$\begin{array}{l}\text { Water-budget } \\
\text { component }\end{array}$} & \multicolumn{2}{|c|}{ Carson River } & \multicolumn{2}{|c|}{ American River } \\
\hline & $\begin{array}{l}\text { Mean } \\
(\mathrm{mm})\end{array}$ & $\begin{array}{c}\text { Standard } \\
\text { deviation } \\
(\mathrm{mm})\end{array}$ & $\begin{array}{l}\text { Mean } \\
(\mathrm{mm})\end{array}$ & $\begin{array}{c}\text { Standard } \\
\text { deviation } \\
(\mathrm{mm})\end{array}$ \\
\hline Precipitation & 1,008 & 373 & 1,384 & 505 \\
\hline PET & 1,237 & 260 & 1,722 & 91 \\
\hline SET & 514 & 134 & 495 & 70 \\
\hline Surface runoff & 64 & 44 & 63 & 56 \\
\hline Subsurface runoff & 336 & 166 & 717 & 358 \\
\hline Ground-water flow & 92 & 31 & 110 & 34 \\
\hline Snowmelt & 752 & 374 & 912 & 375 \\
\hline Simulated streamflow & 492 & 239 & 890 & 439 \\
\hline Observed streamflow & 454 & 232 & 843 & 504 \\
\hline
\end{tabular}

arise because of their different "current-climate" snow configurations and temperature lapse rates.

Simulated annual water-budget components for 1969-90 are listed in table 6. The American River basin receives about 27 percent more precipitation than the Carson River basin and discharges about 45 percent more streamflow annually. Annual snowmelt is about 16 percent greater for the Carson model than for the American model. The average snowmelt period in the Carson River basin (April through June) produces a steeper streamflow peak than in the American (fig. 12). About 55 percent of annual snowmelt in the Carson occurs during these months. This is in contrast to the longer (January through May), intermittent, lower volume snowmelt period in the American River, during which 75 percent of annual flows occur. Monthly surface runoff and subsurface and groundwater flow distributions mirror snowmelt timing in the two basins, with seasonal increases in flow reflecting the availability of excess soil moisture for surface runoff and deep percolation. The proportion of annual streamflow derived from surface runoff for the Carson (13 percent) is almost twice that for the American (7 percent), and surface-runoff timing in the two basins reflects their differing snowmelt periods. During the winter and early spring months in the American basin, excess soil moisture is routed through the system as subsurface and ground-water flow, resulting in seasonal maxima of these flows. In the Carson basin, all three flow components are at a minimum during this period, reaching seasonal maxima in May and June. Differences in soil characteristics also contribute to surface and subsurface runoff distributions. The differences in surface flow contributions in the two basins reflect different snowmelt timing and rates, as well as differences in soil water-holding capacities (the dominant clay-loam soils of the American River basin are assumed to have four times the capacity of the gravelly, sandy soils dominating the Carson River basin).

Annual PET estimates for the American River basin $(1,722 \mathrm{~mm})$ are about 39 percent higher than for the Carson River basin (1,237 $\mathrm{mm})$, whereas annual SET losses for the two basins are within 4 percent of one another. However, SET timing differs for the two basins (fig. 12). Late fall to early winter SET is higher in the American basin than in the Carson basin due to 

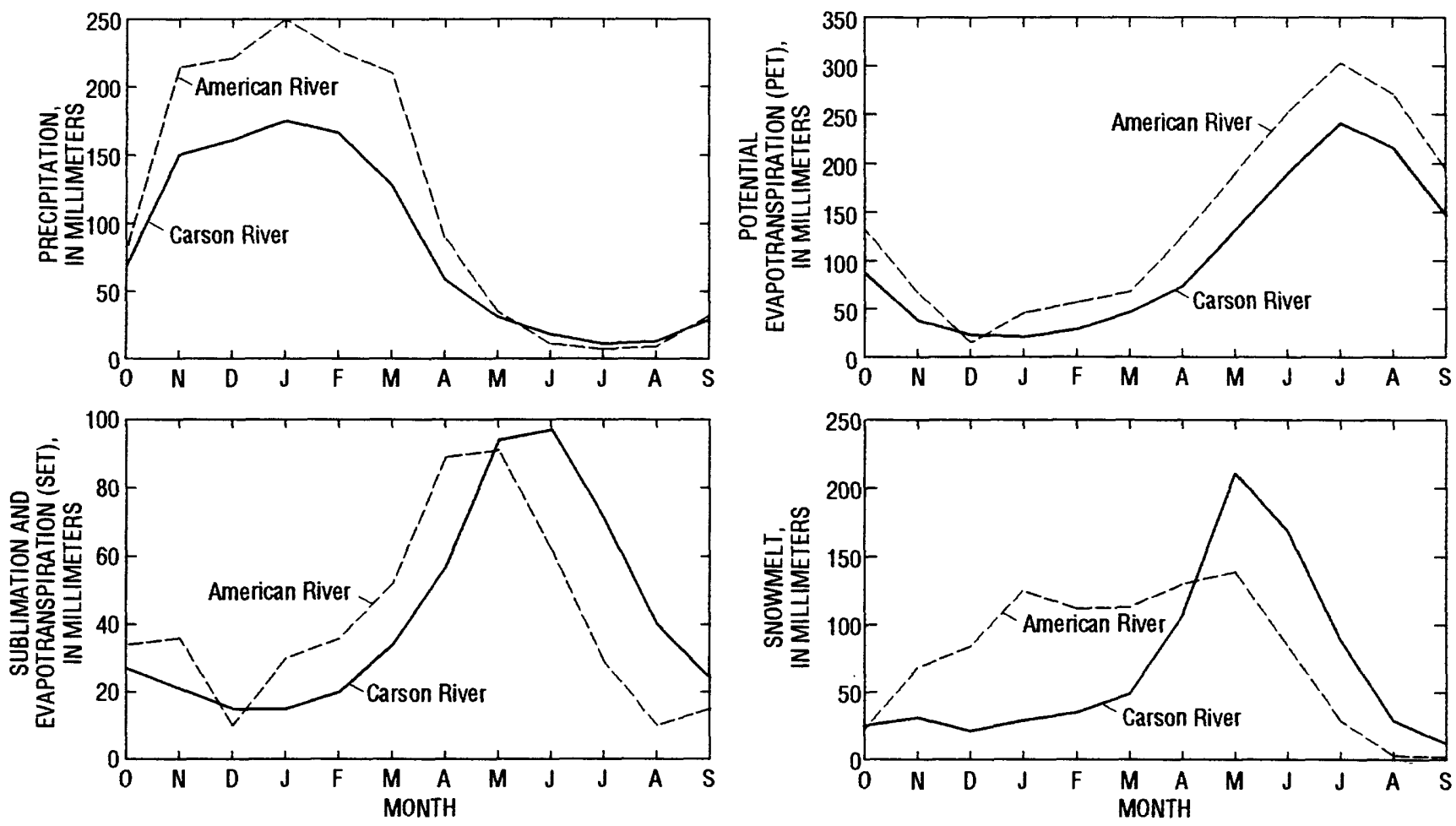

Figure 12. Monthly distribution of water-budget components for East Fork Carson and North Fork American River basins for water years 1969-90.

higher fall and winter PET rates coupled with the availability of soil moisture resulting from intermittent snowmelt. SET in the Carson basin peaks soon after the snowmelt peak and corresponds to the peak of transpiration when the system is least limited by either soil moisture or energy (PET). In both basins, when PET increases during the late summer months (when temperatures are at their annual maxima), soil water generally is limited. Peak soil moisture depletion is during the fall and winter months (but at relatively low rates) in the American River basin and during the early to late spring months in the Carson River basin.

Because more water is trapped in the snowpack until later in the year when PET rates are high in the Carson River basin, overall SET is higher there ( 51 percent of the total budget) than in the American ( 36 percent) where much water escapes the basin as cool-season runoff. Thus, despite higher temperatures and soil moisture-holding capacities in the American River basin, more SET occurs (proportionally) in the Carson River basin. Although altitude is the dominant differ- ence, other characteristics such as slope, aspect, soils, vegetation type, and density may contribute in subtle ways at the basin scale and probably more significantly at the subbasin scale.

Overall, the water-budget components for the two basins appear to have been simulated adequately. Differences between the simulated hydrologic regimes of the lower, warmer American River basin and the higher, cooler Carson River basin are reasonable. These differences also correspond to relations observed in other studies. Although the basins are indeed leeward and windward basins, the most pronounced reason for differences in basin scale hydrology appears to be the different basin altitudes.

\section{MODEL LIMITATIONS}

The spatial distribution of precipitation, precipitation undercatch, temperature lapse rates, and the influence of temperature on precipitation form are pro- 
cesses to which snow-dominated hydrologic models are most sensitive (World Meteorological Organization, 1986; Leavesley, 1989). Model uncertainties also arise because of the simplifications made in the PRMS representations of various hydrologic processes. These various sources of uncertainty are discussed in this section.

Calibration problems for the American model appear to be due primarily to modeling the precipitation form. Previous studies (for example, Cayan and others, 1993) have indicated the importance of climatological influences in snow-dominated basins of California, addressing particularly the effects of seasonal anomalies on temperature and precipitation. High altitude basins (greater than 2,286 m) with considerable snowpack (for example, the Carson) are more sensitive to temperature anomalies occurring in spring and early summer, which affect both streamflow timing and volume. In middle altitude basins (for example, the American), winter temperatures hover near freezing over large areas. This makes these basins more sensitive to changes in cool season temperature. Cayan and others (1993) observed that, for middle altitude basins, anomalous temperatures during February to April are an important influence on late spring streamflow (May through July). The effect of winter temperature anomalies on spring runoff depends largely on the distribution and depth of the snowpack in a given basin and year.

Simulating the correct precipitation form is particularly a problem for middle altitude zones, such as the American River basin, where winter storms carry a significant rain or mixed component. The range of surface air temperatures at which snow may be formed is broad, and calibrated values for the snow threshold temperature can range over several degrees without violating physical reasonableness. The result is a snow threshold value which, though suitable for many storms, may be too warm for others. In turn, simulated snow accumulation or snowmelts may suffer, especially during warm storms, which are particularly large precipitation contributors in the Sierra Nevada (Cayan and Riddle, 1992). Simulating precipitation form is presumably easier in much of the high altitude Carson River basin where winter temperatures generally are well below $0^{\circ} \mathrm{C}$ and nearly all precipitation falls as snow.
Some of the problem with the Carson model may be attributable to the paucity of climate stations used, as well as the spatial distribution of some of the dominant HRU's. The basin partitioning scheme described earlier does not take into account changes in precipitation across latitude, a climatic characteristic that may be present in the north-central Sierra Nevada. In addition, monthly lapse rates for both precipitation and temperature do not reflect the variability in daily lapse rates, which can be a source of modeling error. Clearly, more numerous and better distributed climate data would reduce some of the simulation uncertainties.

Problems with the simulated timing of snowmelt may be partly related to how PRMS represents dynamics of warm snowpacks. PRMS tends to simulate fairly constant winter snowmelt in the American model, whereas, in actuality, winter snowmelt is intermittent and results in less overall winter streamflow. A season long snowpack is thus maintained, and more snowmelt and streamflow occur later in the year. Smith (1974) observed in data collected at the Central Sierra Snow Lab that water moves through the relatively warm snowpacks of the Sierra Nevada at snow densities as low as $0.2 \mathrm{~g} / \mathrm{cm}^{3}$ (in contrast to previous reports of a lower limit of $0.4 \mathrm{~g} / \mathrm{cm}^{3}$ ). Rapid, intermittent snowmelt is also facilitated or initiated in the warm snowpacks of the Sierra Nevada when rain falls on snow. PRMS addresses both of these issues but perhaps not accurately enough for the Sierra Nevada.

Losses from the snowpack by sublimation are probably significant, although no observations are available for the study basins. Dozier and Melack (1989) estimated that sublimation accounted for 80 percent of total annual loss to the atmosphere in a study at the Emerald Lake watershed in Sequoia National Forest in the southern Sierra Nevada. This may be higher than in either the Carson or American River basins because the Emerald Lake basin essentially has no vegetation cover and thus no transpiration losses. Still, their results suggest that sublimation may be important in the study basins, and thus that some limitations of PRMS's estimates need to be considered. PRMS assumes that no sublimation occurs while plants are transpiring. However, in the American River basin, the highest plant water use occurs during the early spring when several feet of snow may 
remain on the ground (Smith, 1974). Thus, sublimation may be underestimated. If so, the effect would be to prolong simulated snowmelt into the late spring.

The net shortwave and longwave components of the snowpack energy budget critically depend on estimates of winter canopy cover (eq. 2) so that errors in canopy cover affect simulated snowmelt and streamflow timing. For example, when the American River basin winter canopy cover was increased by 20 percent and the transmission coefficient was adjusted accordingly, the onset of spring snowmelt was delayed by several weeks. Canopy cover for the Carson model was estimated from sample sites within the basin and inferred for the American model from Landsat thematic mapper (TM) data using a forest canopy reflectance model developed by Woodcock and others (1990). The spatial correspondence between the coarse resolution land-cover data, used in HRU delineation for vegetation typing, and the TM vegetation classification, used to determine canopy density, was not determined. Absorption of incoming shortwave radiation by the snowpack is a function of the snow albedo and the canopy transmission coefficient. The latter coefficient is estimated from vegetation type and density; in this study, the coefficients were developed from Miller's (1959) study of various species of pine and fir. In lieu of other data, Miller's relation also was applied to range and deciduous forest type.

In this study, sensitive parameters such as precipitation correction factors and temperature lapse rates are assumed to be constant for the calibration and verification periods. Monthly streamflow (fig. 9) simulated by the American model for the verification period was more similar to the timing of monthly streamflow during the calibration period than to the timing during the verification period. Observed AprilMay streamflow was 17 percent less during the calibration period (1969-90) than during the verification period (1949-68). If the trend toward decreasing spring streamflow during the calibration period was caused by increasing minimum temperatures, as suggested by Pupacko (1993), and if this temperature trend is present in the historical temperatures used to drive the model, PRMS should be able to adjust accordingly. If, however, the temperature lapse rate also changed between the two periods, then use of constant temperature (and even precipitation) distribution parameters over the 42 years may not be suitable.
Although they contribute to greater spatial resolution of the models, spatially noncontiguous HRU's also contribute to model uncertainties. Runoff, snowmelt, soil moisture depletion, and other water- and energy-budget components are difficult to localize and check unless the spatial scatter of HRU cells is minimized. HRU scatter also presents problems in indexing HRU's to particular climate stations where climatic variations are not solely dependent on elevation. To illustrate, when advanced very high resolution radiometer (AVHRR) snow-cover data are correlated to HRU-simulated snow cover, correlation is poor for HRU's with extensive scatter. This may be in part due to overly broad HRU definitions, particularly for the grouped altitude layer. Introducing a layer that describes proximity to climate stations into the HRU delineation process may reduce some of the spatial scatter and may improve the estimation of weather variations throughout the basin. For example, recent studies (Hay and others, 1992; Leavesley and others, 1992) have driven PRMS with precipitation series from the RHEA-CSU orographic-precipitation model. Initial results indicate that the spatial distribution of precipitation is better represented by the orographic model than by the point-measured precipitation, and yields improved streamflow simulations.

Finally, the PRMS models for the Carson and American River basins are static models. River basins are dynamic systems. Interannual to interdecadal vegetation changes are likely to affect hydrologic processes such as snowmelt, evapotranspiration, soil-zone moisture depletion, and subsurface flow. As indicated earlier, a 20-percent change in canopy results in streamflow timing changes of several weeks. However, spatial distributions and densities of vegetation in the HRU's are assumed to be constant in this implementation of PRMS, regardless of climate or maninduced changes to the basin.

\section{SYNTHESIS OF CLIMATE-CHANGE SCENARIOS}

The magnitudes and directions of climate change that can influence water-resources decisions over the next century are highly uncertain in the Sierra Nevada region. Global climate models currently 
project equilibrium warming of about 2 to $5^{\circ} \mathrm{C}$ (depending on model) in response to doubling of carbon dioxide in the atmosphere, but they differ in what seasons will see the greatest warming (Mitchell and others, 1991). Regional projections of temperature changes vary at least as widely from model to model. Projections of precipitation change from these models are even less unanimous in both direction of change and magnitude. Uncertainty in projections of climate change is compounded by the large range of long-term natural climatic variability that may influence climate, with or without a greenhouse effect (Folland and others, 1991). Consequently, investigations of regional sensitivity plausibly could consider a wide range of climate-change conditions. In this report, warmer and cooler, and wetter and drier, scenarios are examined.

In this study, 100-year scenarios were synthesized to reflect observed spatial and temporal statistics of temperature and precipitation (from 1948-88) at each site used to drive the calibrated models, but with equilibrium changes in mean temperature and precipitation superimposed. In order to recreate most of the annual scale variability of precipitation and streamflow, a wetter-than-median weather model and a drierthan-median weather model were developed and sampled at random during the 100 years of each synthesis. Daily minimum and maximum temperatures were drawn from spatially correlated normal distributions with first and second moments that depend on wetness and time of year. Regional precipitation occurrence was determined by Markov models, and precipitation rates were drawn from spatially correlated gamma distributions. Statistics of the Markov models and gamma distributions depend on wetness and month of year. The WGEN weather synthesis program (Richardson and Wright, 1984) was used to generate regional climate series, which then were distributed into site values using methods paralleling those of Todini (1980), but without his requirement that site values average to the regional values except on longterm average.

Synthetic means and standard deviations of precipitation and temperatures for the two basins can be compared with their historical counterparts in figure 13 using the model estimates of potential evapotranspiration (PET) as a surrogate for basin average temperatures. Most of the differences between historical and synthesized precipitation and PET are due to dif- ferent periods used to calibrate the synthesis procedure (1948-88) and the historical streamflow simulations (1949-90 for American and 1969-90 for Carson). Also, temperatures for the Carson River basin were given an unrealistically sinusoidal seasonal cycle by the WGEN program. Although not shown here, skewnesses were reasonably well reproduced, and those skews that were not in good agreement differed due to just a few extreme events. The synthetic series reproduced high and low quartile values of precipitation. Intersite correlations of both precipitation and temperatures were reproduced. Tables allowing more detailed comparison of historical and synthetic statistics are available from the authors.

For each basin, 24 "uniform-change" climate scenarios and 1 current-climate scenario were synthesized. In the climate-change scenarios, mean temperatures (both minimum and maximum) and precipitation likelihoods and rates were changed uniformly throughout the year and equally at all sites. These scenarios were used to drive the streamflow models with climate changes ranging from -25 to +25 percent of mean precipitation and $-4.4^{\circ} \mathrm{C}\left(8^{\circ} \mathrm{F}\right)$ to $+4.4^{\circ} \mathrm{C}$. Four additional scenarios were synthesized for each basin in which mean temperatures and precipitation were changed separately in each month of the year to reflect mean monthly changes simulated in general-circulation climate-model simulations under doubled $\mathrm{CO}_{2}$ conditions. Humidity, longwave emissions, wind speeds, and landscape properties, such as vegetation type and density, were assumed to be unchanging from current conditions despite the effects that climate change probably would have on each. Due to the estimation procedure for solar radiation used in the PRMS model, cloudiness effectively increased (decreased) as imposed temperatures decreased (increased).

Basin responses that will be described in the remainder of this paper are compared to simulated responses to 100 -year synthetic climate series in which no changes were imposed relative to climate statistics estimated from the $1948-88$ record. Mean water-budget components under these current-climate scenarios are the second pair of rows in tables 7 and 8 , whereas components from simulations using historical temperature and precipitation series are described by the first pair of rows. The annual water-budget components for the two simulations compare favorably in both means and standard deviations, indicating that 


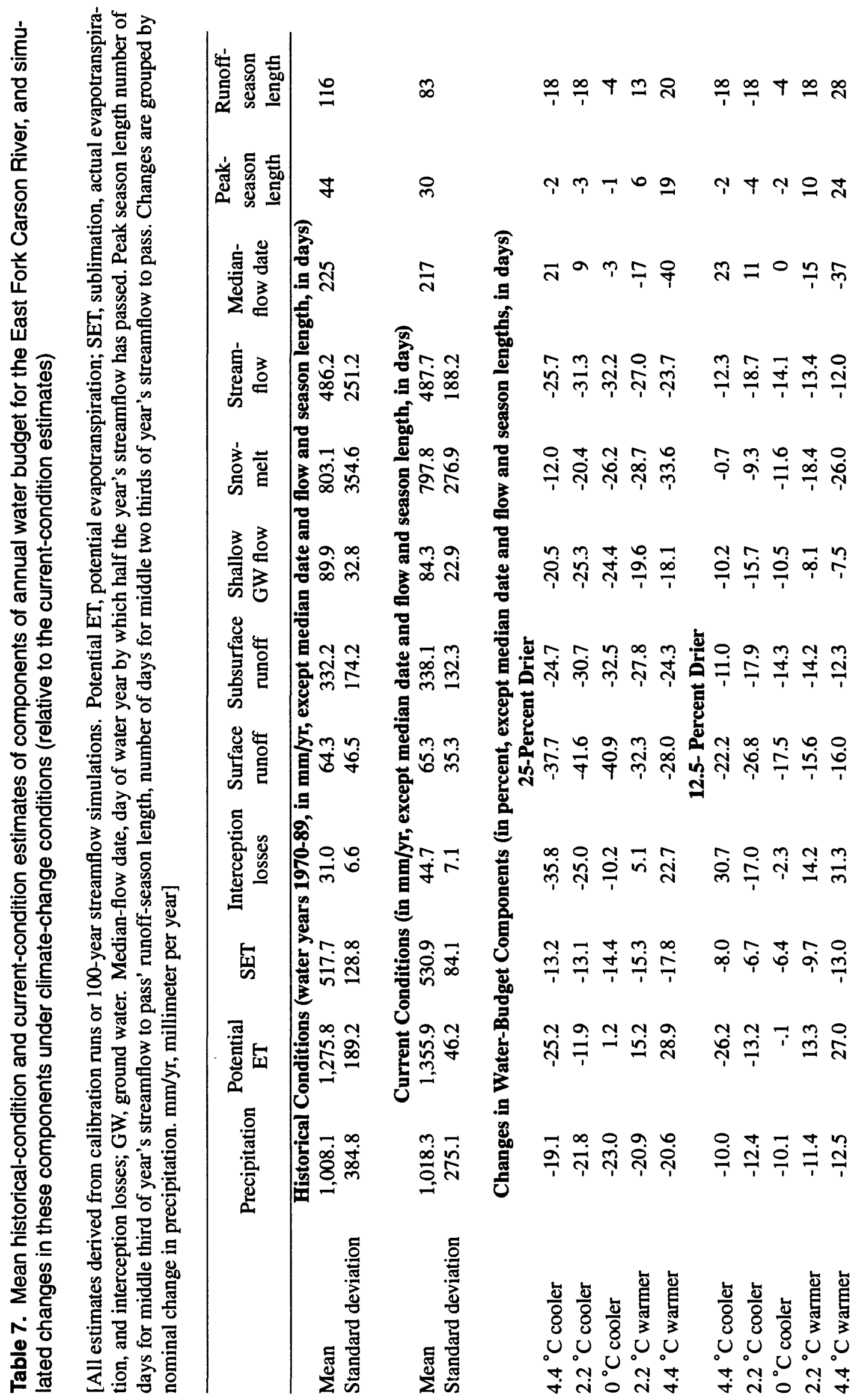




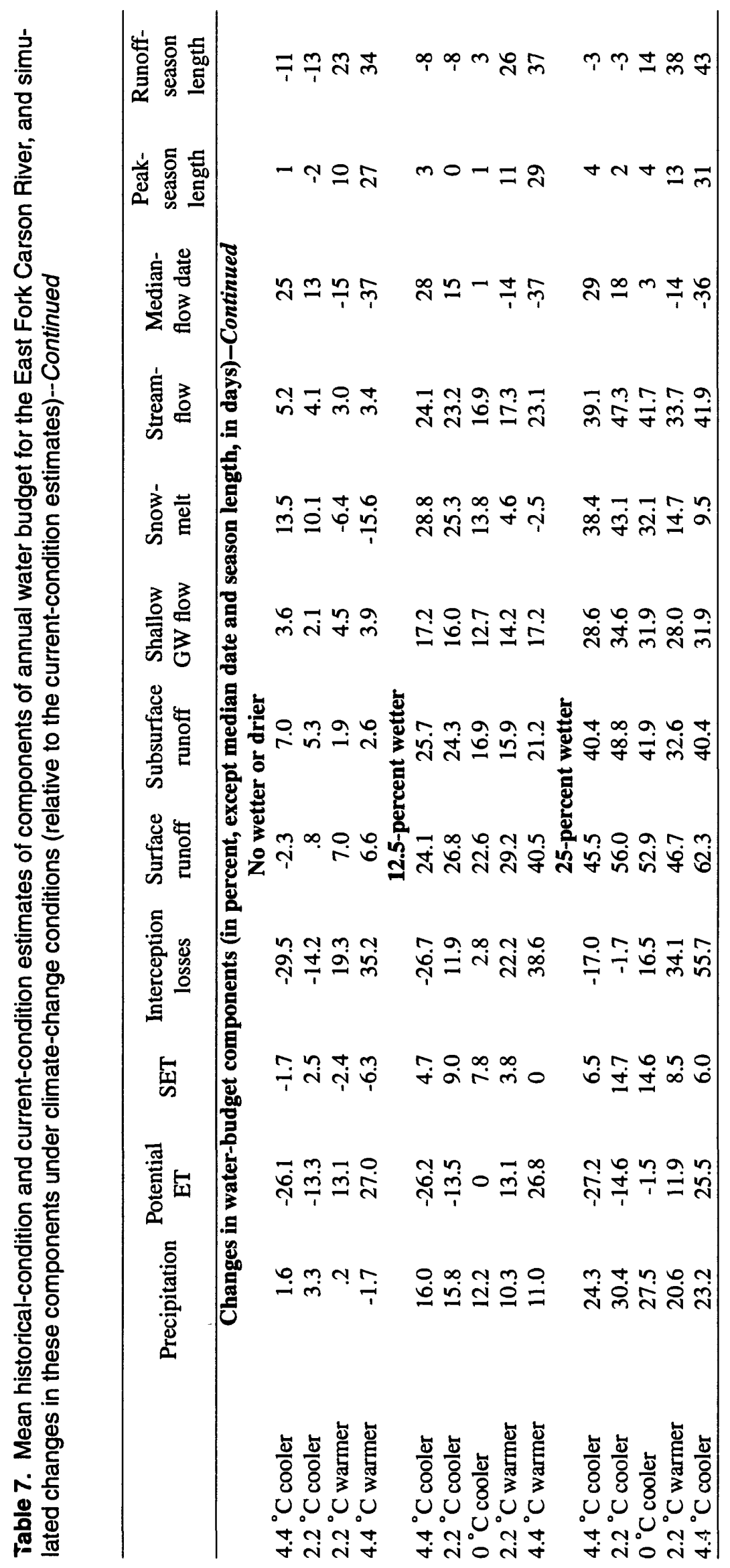




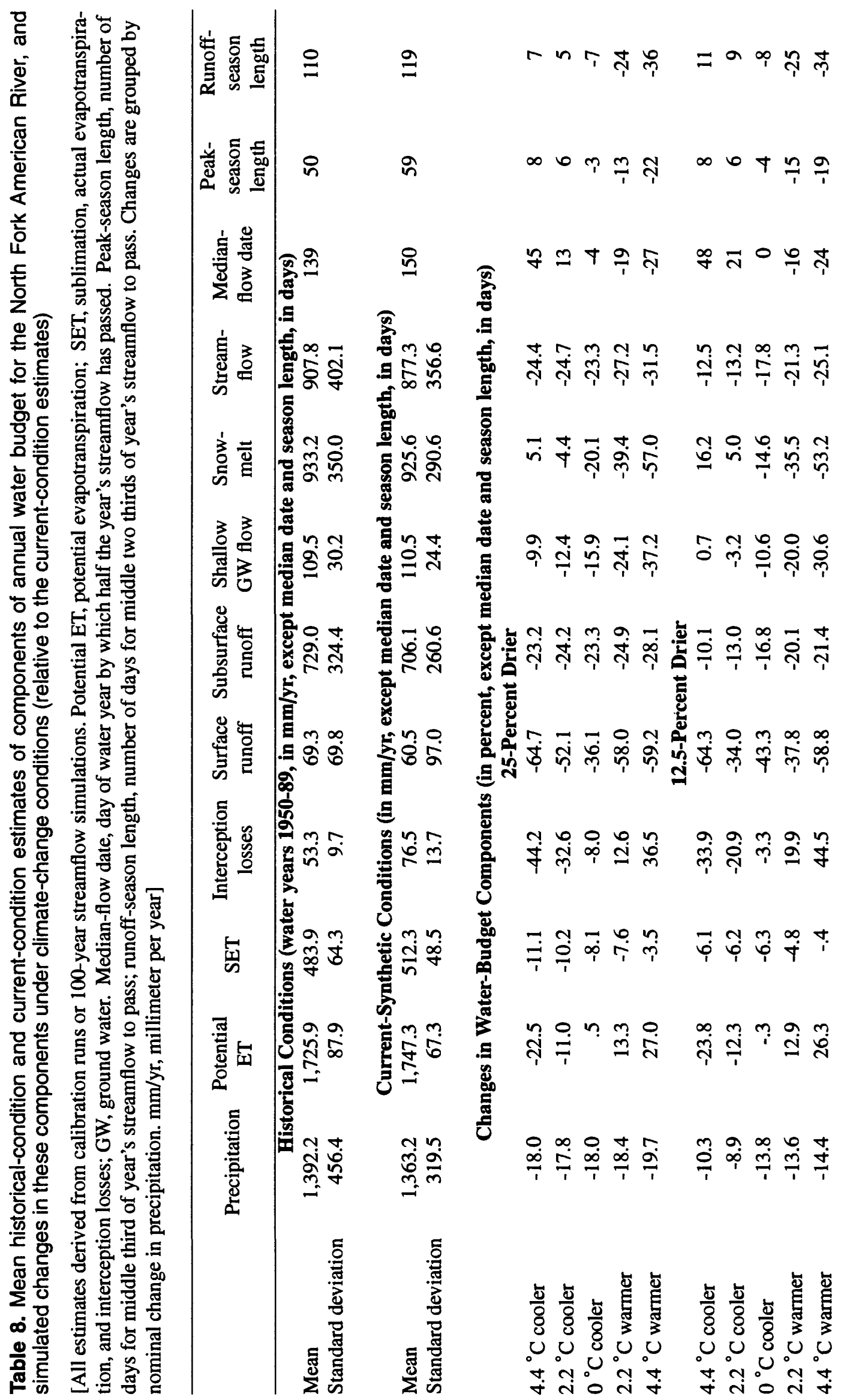




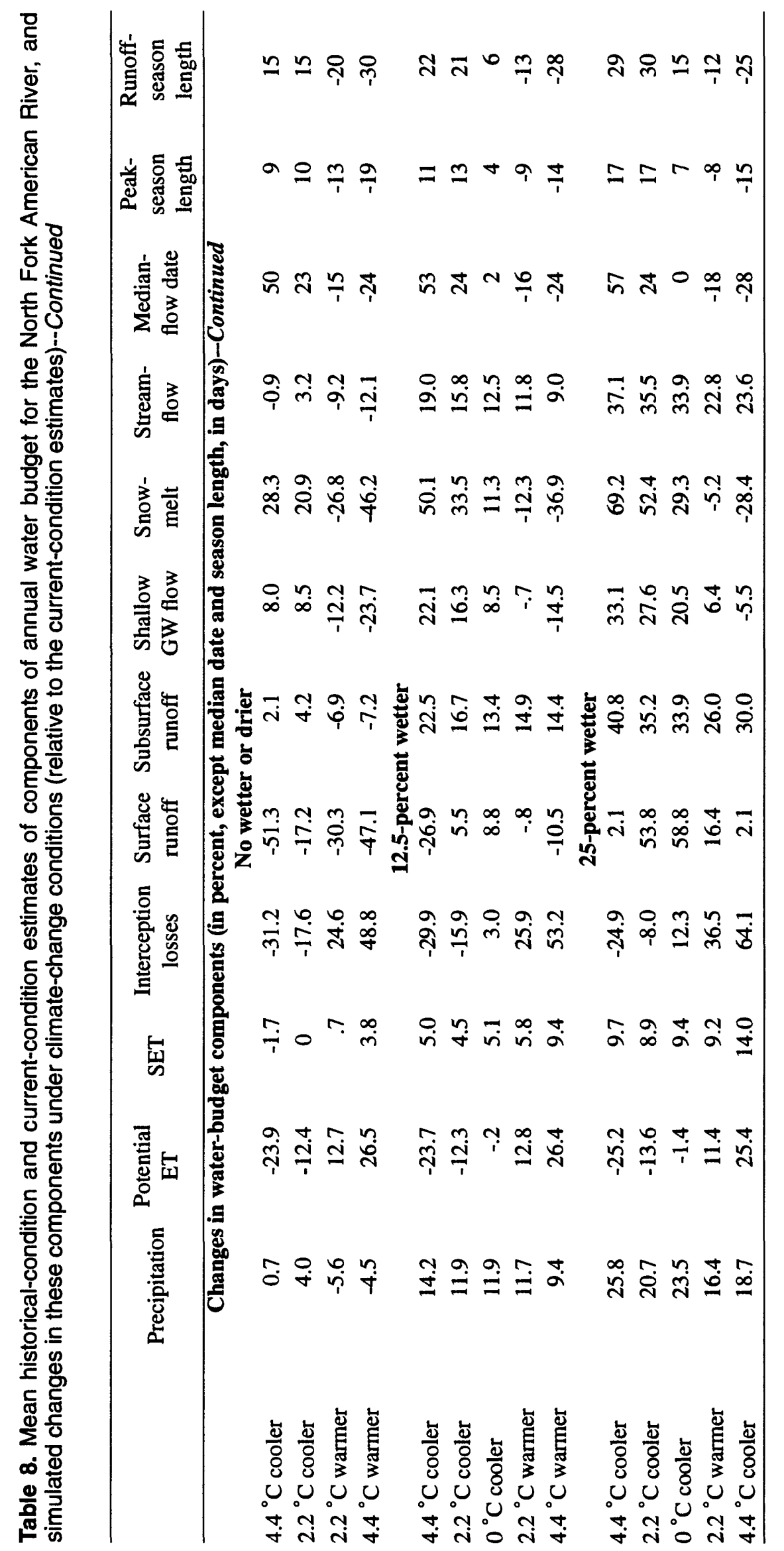



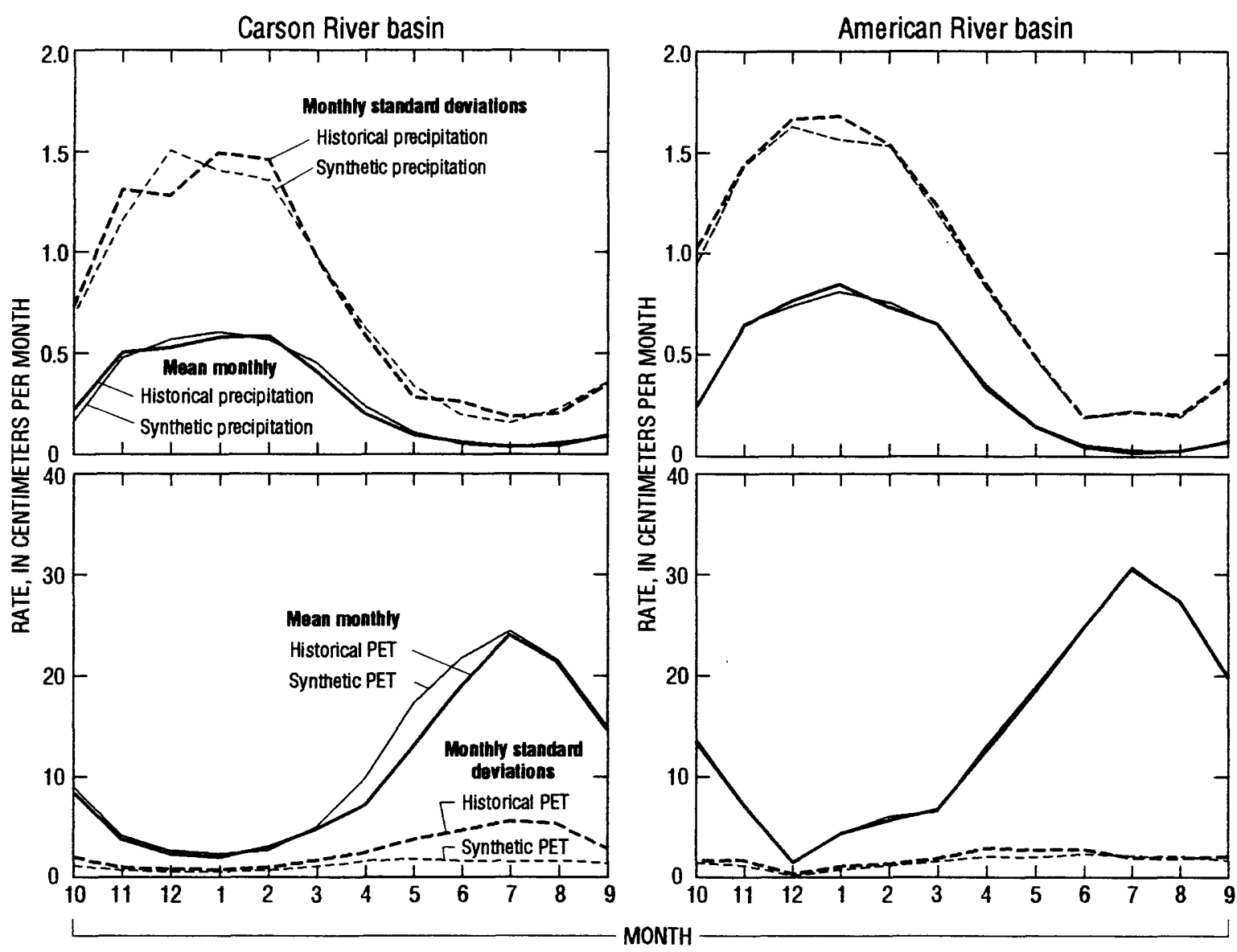

Figure 13. Historical and synthetic current-condition climates (precipitation and potential evapotranspiration) as distributed and areally averaged by streamflow model. Historical rates are based on intervals 1969-90 for Carson River basin and 1948-90 for American River basin.

the current-condition synthetic series reflects the historical climate adequately for the purposes of this analysis. These comparable responses are a reflection of the close correspondence between historical and synthetic climate series shown in figure 13. Although not shown here, recurrence intervals of the historical and synthetic simulations are in close agreement in the Carson River basin, whereas simulations for the American River basin under synthetic conditions tend to underestimate somewhat the variability of annual flows. On the whole, however, the synthetic currentcondition scenarios are able to drive the precipitationrunoff models to realistic long-term variability.

\section{BASINWIDE RESPONSES TO CLIMATE- CHANGE SCENARIOS}

Simulated basin responses to climate changes are discussed in this section. Unless otherwise noted, all responses described below are model simulated. Basin responses are discussed here in terms of 100 year average changes, but also could have been determined from (1) shorter simulation periods or (2) qualitatively by considering extreme years instead of average years. For example, similar average changes were obtained when simulations were only 75 years long. In some cases, simulations as short as 10 years were sufficient to qualitatively outline the responses. Recurrence-interval plots for annual streamflows and SET (not shown) indicated that average-year responses were not qualitatively different from responses in years with 1 - to 100 -year recurrence intervals.

Basin responses were tested for the presence of monotonic trends in year-end moisture in order to determine whether any scenario was so severe that it induced a gradual accumulation (or decline) of moisture in the basins from year to year. No statistically 
significant monotonic trends were found (at 95-percent confidence levels) by Kendall-tau tests (Press and others, 1989) of simulated September subsurface flows or soil moisture contents. If any monotonic trends occurred, they were masked by the random interannual variability. Thus, results that follow are considered to be equilibrium responses to the imposed climate changes.

\section{RESPONSES TO CHANGED PRECIPITATION SCENARIOS}

When mean precipitation is changed without changing temperature statistics, the response is a relatively straightforward increase or decrease in streamflow. Mean annual hydrographs for the basins are shown in figure 14 for current conditions and scenarios in which mean precipitation is changed. In the

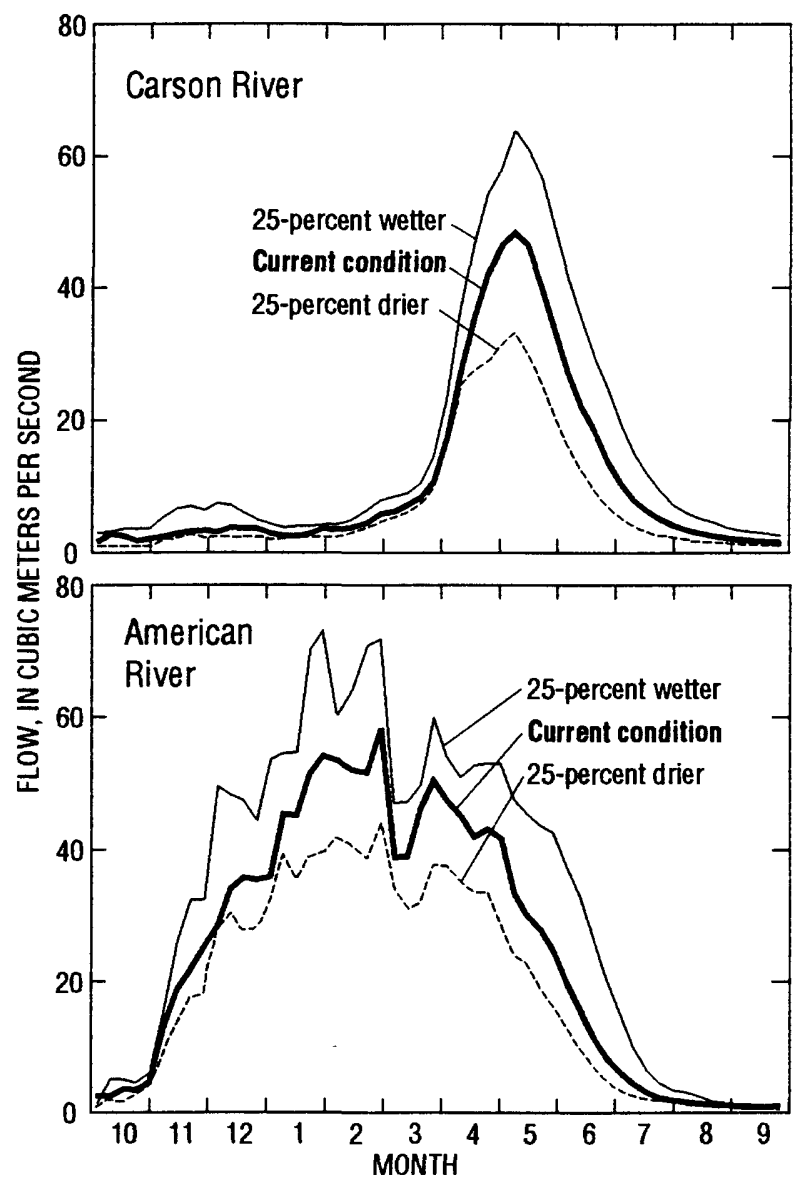

Figure 14. Simulated mean streamflows under scenarios in which mean precipitation is changed for East Fork Carson and North Fork American Rivers.
American River basin, changes in precipitation are reflected in streamflow throughout the year; in the Carson River basin, the dominant streamflow response is postponed until the spring snowmelt. Tables 7 and 8 contain the changes in the means of various waterbudget components under these scenarios. Recurrence-interval analyses indicated that the basins did not respond to precipitation changes disproportionately during either the wettest or driest years.

SET from the two basins is generally water limited. That is, when more water is available, more SET occurs. When less precipitation falls, less SET occurs. Annual streamflow increases or decreases actually are somewhat greater than proportional to the changes in precipitation. Also, increases in precipitation lead to slightly larger streamflow changes than do decreases in precipitation. Both the "amplification" of the precipitation changes in the runoff totals and the greater sensitivity to increases in precipitation (within the range considered here) are in keeping with the "amplified" sensitivity to precipitation changes found by Karl and Riebsame (1989, fig. 8) for streams throughout the United States.

Notice that, although the annual PET does not change with changes in precipitation alone (tables 7 and 8), SET varies directly with the changes in water made available by precipitation. SET changes are about half as large (proportionally) as the specified changes in mean precipitation, mostly because much of the added precipitation comes during cold winter months when energy limits SET more than does moisture. SET in the Carson River basin increases (decreases) more with precipitation changes than does SET in the American River basin (tables 7 and 8) because most water in that basin is stored in the snowpack until late spring when more energy is available. When more energy is available, PET increases. In the American River basin, much of the added precipitation either melts early or falls as rain and thus runs off when PET is limited. Because annual streamflow is equal to precipitation minus SET in the models, the smaller-than-proportional changes in SET with changing mean precipitation are reflected as "amplified" streamflow responses.

Changes in annual total snowmelt are almost proportional to the specified changes in mean precipitation. These responses are accomplished mostly by 
increasing the water content in the snowpack with only small changes in snow-covered areas from one scenario to another. The second and fourth dots on the curves in figure 2 show the average April snow cover under the wetter and drier scenarios, respectively. Differences in each case are about 10 percent from the current-condition snow-covered areas. In contrast, changes in April snowpack water content vary between about -30 percent in the driest scenarios and +50 percent in the wettest in both basins. Without accompanying temperature changes, the April snowline remains almost constant, whereas snowpack water content varies considerably upslope from the snowline.

\section{RESPONSES TO CHANGED TEMPERATURE SCENARIOS}

The central rows in tables 7 and 8 present responses to scenarios in which mean temperature is changed without changing precipitation statistics. In response to mean-temperature changes between -4.4 and $+4.4^{\circ} \mathrm{C}$, the simulated annual PET changes almost linearly between about -25 to +25 percent of the current-condition rates. Thus, among the scenarios considered here, the range of changes in annual PET is equivalent to the range of changes in the amounts of water supplied to the basins by precipitation. Initially then, one might expect streamflow responses to the temperature and precipitation changes imposed here to be of similar magnitudes. However, streamflow responses to temperature are not this simple.

Probably the most dramatic responses to changes in mean temperatures are shifts in the timing of hydrologic fluxes in the two basins. These shifts are of concern to water managers because they can "release" water from the basins prior to (or after) the use-and-storage plans currently in operation and thus waste much water. Similar shifts in the timing of hydrologic fluxes are described for basins on the west side of the Sierra Nevada by Gleick (1987a) and Lettenmaier and Sheer (1991). These authors also describe (in greater detail than here) the potentially severe water-management consequences of such shifts in timing. However, besides changing the character of the annual hydrographs in the basins, the shifting hydrologic fluxes also interact to alter and, to an extent, buffer the effects of changing mean temperatures on the total annual flows. Because of this link- age, the timing of fluxes would be important even if runoff timing were not a management issue.

Changes in streamflow timing will be quantified here in terms of changes in the median-flow date (MFD) and in peak and runoff season lengths (PSL and RSL). In this paper, MFD is defined as the day of a water year by which half of the total streamflow for that year has passed. This date describes the center of mass of the annual hydrograph and is a simple scalar indication of the runoff timing that is most useful in basins with one dominant snowmelt-runoff peak. PSL is defined (arbitrarily) as the number of days required for the middle one third of the streamflow for a water year to pass, and RSL is the number of days for the middle two thirds to pass. These season lengths are intended to be reproducible, scalar indications of the amount of time during which flows are highest (peak season) and during which most economically significant flows occur (runoff season).

Streamflow timing changes in the Carson River in response to these scenarios are evident in figure 15a and table 7 . Under the $4.4^{\circ} \mathrm{C}$ cooler scenario, figure 15 a shows that streamflow almost ceases during winter months. The snowmelt-runoff peak arrives about 14 days later and the summertime recession is slower. However, the peak flow is not much changed in magnitude on average. MFD is delayed by 25 days relative to the current-condition simulation. RSL is only slightly less than under the current-condition simulation, and PSL is essentially unchanged. The delay in the peak runoff curve reflects a delay in the peak snowmelt under the cooler scenario (fig. 15c). In the snowmelt hydrograph (as in the streamflow hydrograph), the peak melt is delayed, and the summer recession is slower under the cooler scenario than under current conditions. Snow constitutes somewhat more than 78 percent of the total precipitation under current conditions and more than 88 percent under the cooler scenario. (The PRMS model only reports total snow minus annual sublimation.) During winter months, snowmelt is less under the cooler scenario, and because winter temperatures, PET, sublimation "potential," and liquid moisture are less, winter SET is reduced under the cooler scenario (fig. 15d). During the rise toward the streamflow and snowmelt peaks, SET is always less under the cooler scenario than under current conditions. During the summer streamflow recession, more soil moisture remains available, 

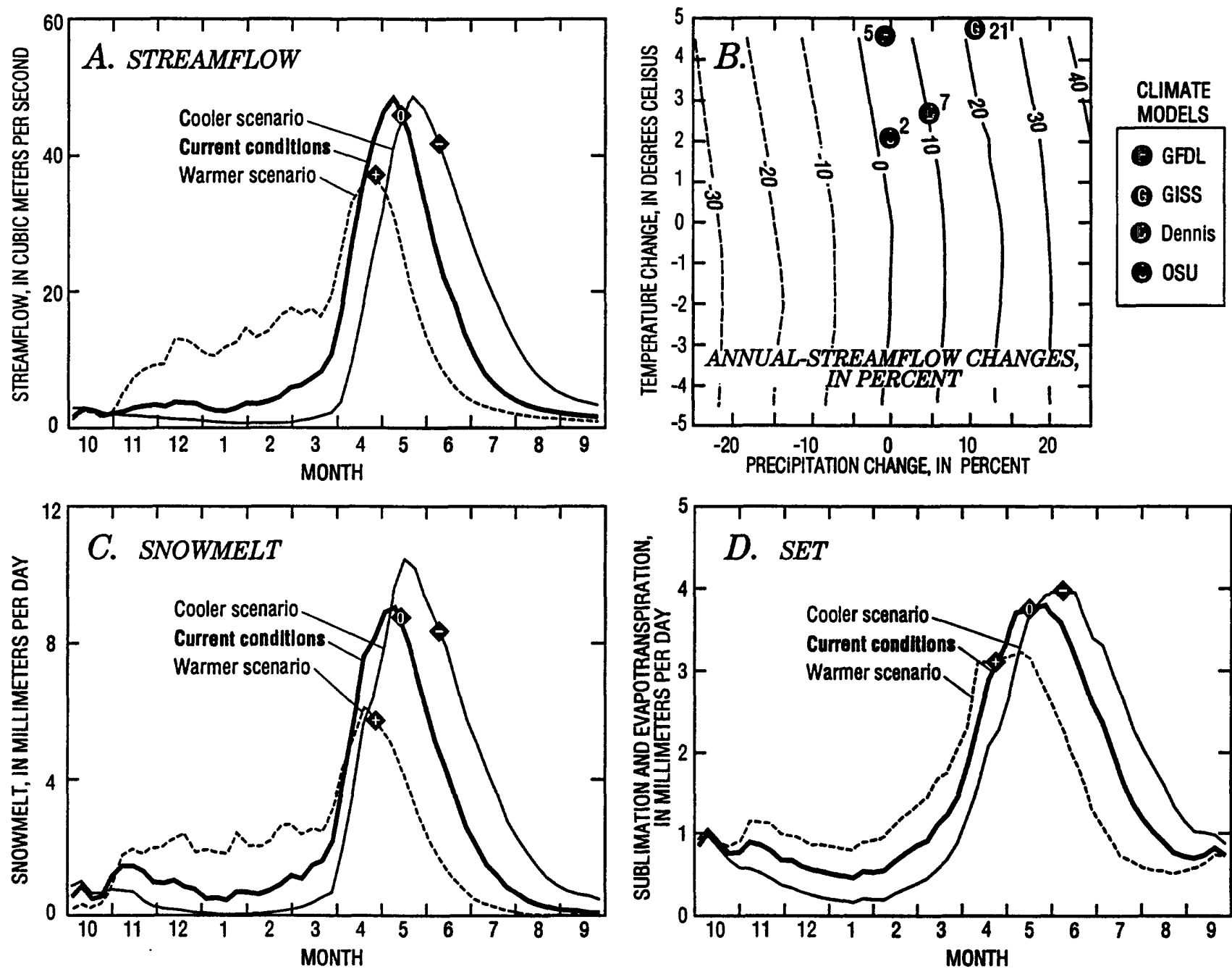

Figure 15. Simulated water-budget responses to uniform-change scenarios in the East Fork Carson River basin. $A, C$, and $D$ illustrate mean changes under scenarios in which mean temperatures are changed, and $B$, percentage changes as function of changes in both mean temperature and mean precipitation (contours for uniform-change scenarios - dashed where negative; symbols for climate-model scenarios). Diamonds " + ", " 0 ", and "-" indicate the time when potential evapotranspiration is equal to that during the current-condition SET maximum for the warm $(+)$, current $(0)$, and cool $(-)$ scenarios, respectively. Labelled circles in $B$ are percentage changes for four climate-model scenarios described in text.

and SET is larger under the cooler scenario. The overall result is that winter and summer changes balance, and annual SET is only about 2 percent less than under the current climate.

The annual hydrograph for the American River also responds to the cooler scenario with a delayed spring runoff peak (fig. 16a). However, the cooler scenario does not simply shift the hydrograph peak (as happened in the Carson River simulation), but rather changes its entire shape. The February runoff peak, which corresponds to the almost immediate release of the winter precipitation maximum, still occurs under the cooler scenario, but is reduced by 30 percent. The snowmelt runoff peak (which occurs in April under current climate) is delayed and much enhanced under cooler conditions, so that the annual hydrograph approaches the snowmelt-dominated hydrograph form found in the higher, colder Carson River. In the American River, MFD is almost 2 months later under the $4.4^{\circ} \mathrm{C}$ cooler scenario. Because runoff continues to increase until late spring under this scenario while 

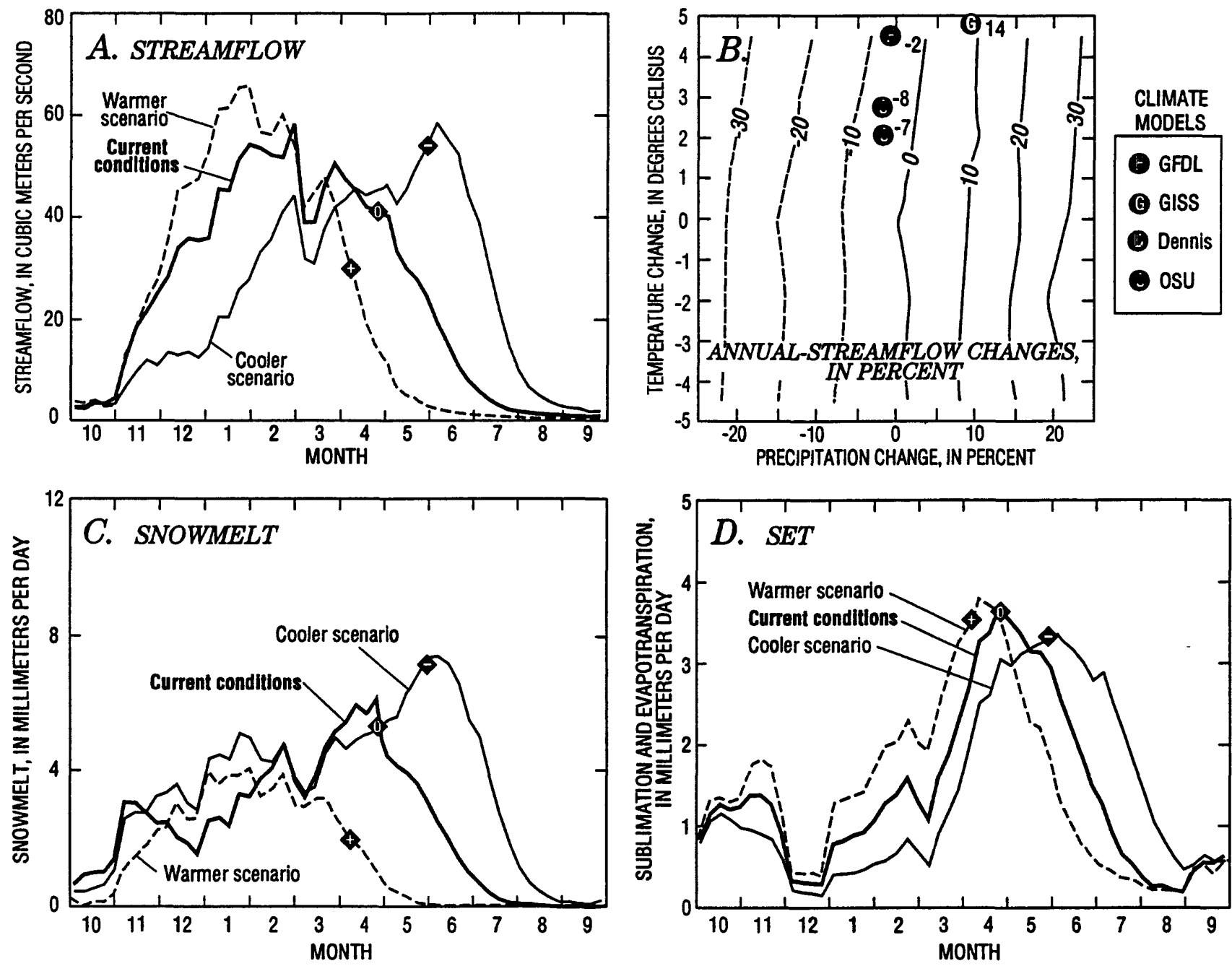

Figure 16. Simulated water-budget responses to uniform-change scenarios in the North Fork American River basin. $A, C$, and $D$ illustrate mean changes under scenarios in which mean temperatures are changed, and $B$, percentage changes as function of changes in both mean temperature and mean precipitation (contours for uniform-change scenarios-dashed where negative; symbols for climate-model scenarios). Diamonds " + ", " 0 ", and "-" indicate the time when potential evapotranspiration is equal to that during the current-condition SET maximum for the warm (+), current (0), and cool (-) scenarios, respectively. Labelled circles in $B$ are percentage changes for four climate-model scenarios described in text.

maintaining a sizeable winter runoff rate, RSL increases by 15 days (table 8 ). The increase in PSL is less. Under current conditions, snow constitutes more than 69 percent of the annual precipitation, whereas under the $4.4^{\circ} \mathrm{C}$ cooler scenario, snow is more than 81 percent of the total. Peak SET is delayed about 35 days and lasts longer (fig. 16d), but the net effect is only 2 percent less total SET than under the current climate.

Under warmer scenarios, the mean streamflow hydrograph for the Carson River is typified by more winter and early spring snowmelt and runoff. The hydrograph for the $4.4^{\circ} \mathrm{C}$ warmer scenario is shown in figure 15a. A much reduced peak streamflow occurs about 2 weeks earlier, and streamflow has essentially ended by late June. MFD is $\mathbf{4 0}$ days earlier on average, and PSL is about twice that under current conditions (table 7). This quickening of the runoff peak is comparable to snowmelt timing simulated by Tsuang and Dracup (1991), who projected snowmelts in a higher altitude basin nearby that were 19 to 92 days earlier than current conditions under warmer climate 
scenarios. Snowmelt (fig. 15c) occurs throughout the winter months under the warmer scenario, and the peak snowmelt (and thus, peak streamflow) is less because less snowpack forms and more melts by the time temperatures rise in late spring. Under the warmest scenario in the Carson River basin, 16 percent less total snowmelt occurs (table 7), and about 67 percent of precipitation is snow.

Under the warmest scenarios, streamflow in the American River is earlier and approximates the precipitation timing. MFD is 24 days earlier under the warmer scenario than under the current-condition scenario, and RSL is 30 days less (table 8). These timing shifts are similar to shifts projected by Lettenmaier and Sheer (1991) and are at the low end of shifts projected for a higher altitude basin by Tsuang and Dracup (1991). Because winters are warmer under this scenario, snow constitutes only somewhat more than 38 percent of the total precipitation compared with 69 percent under current conditions. Snowmelt occurs much earlier in the winter season and is almost complete by March and April (fig. 16c). SET rates generally are higher under the warmer scenario (than under the other scenarios) until May (fig. 16d). Under the warmer scenario, current-condition March SET rates prevail during most of the winter. However, the summertime SET rates are much reduced because of the early runoff and depletion of moisture before summer PET rates develop. Changes in annual SET due to increased winter SET and decreased summer SET nearly compensate so that annual streamflow and SET totals respond only marginally to the imposed warmer temperatures.

These changes in streamflow timing in response to temperature changes are in agreement with results from previous studies in the Sierra that employed simpler streamflow models (Flaschka and others, 1987; Gleick, 1987a; Lettenmaier and Gan, 1990). Also, Aguado and others (1992) found significant shifts in streamflow timing due to historical temperature variability in the Sierra Nevada.

Annual total SET responds only weakly to the imposed changes in mean temperature and PET (tables 7 and 8). As a consequence, the annual total streamflow is relatively insensitive also. Generally, with increasing temperatures, mean streamflows increase slightly in the Carson River and decrease in the Amer- ican River. The insensitivity of total SET and therefore streamflow to mean temperature changes is generally in keeping with the results of Karl and Riebsame (1989), who found that historical mean temperature variations of up to $1^{\circ} \mathrm{C}$ annually and $2^{\circ} \mathrm{C}$ seasonally induced "minimal" streamflow changes in 82 streams nationwide. Similarly, Gleick (1987a, p. 394) found with his water-balance model of the Sacramento River Valley that "the average annual runoff volumes do not change significantly between the two cases [historical and climate changes]." The reasons for this insensitivity are discussed more in the next section.

\section{RESPONSES TO SIMULTANEOUS CHANGES IN PRECIPITATION AND TEMPERATURE}

The remainder of tables 7 and 8 , and much of the remaining discussion, addresses responses to scenarios in which mean temperature and mean precipitation are changed simultaneously. Scalar responses are illustrated by contour plots like figures $15 \mathrm{~b}$ and $16 \mathrm{~b}$. In these plots, the closer the curves are horizontally, the more sensitive the scalar is to changes in mean precipitation. Greater tilt of the curves from vertical indicates sensitivity of the scalar to changes in mean temperature. Tilts to the left indicate that the scalar increases with warming.

Changes in MFD and PSL in response to the scenarios are shown in figure 17. In general, warmer scenarios lead to earlier snowmelt and earlier runoff. MFD is earlier in the warmer scenarios, almost regardless of the year-long precipitation changes imposed in these scenarios. Curves are farther apart toward the cooler, lower half of figure $17 \mathrm{a}$, reflecting smaller delays in peak runoff in the Carson River under the cooler scenarios (fig. 15a). In contrast, figure 17c shows that, in warmer scenarios, greater and greater temperature increases are necessary in the American River basin to hasten the rain-dominated runoff peak. Under the warmer scenarios, PSL and RSL increase in the Carson River basin and decrease in the American River basin (fig. 17b and 17d). The springtime snowmelt-runoff peaks do not broaden much in the Carson River basin in response to warmer conditions, but winter snowmelt and runoff do increase. Consequently, runoff is more persistent and the season lengths increase. In contrast, the spring snowmelt-runoff peak is all but eliminated under the warmest American 


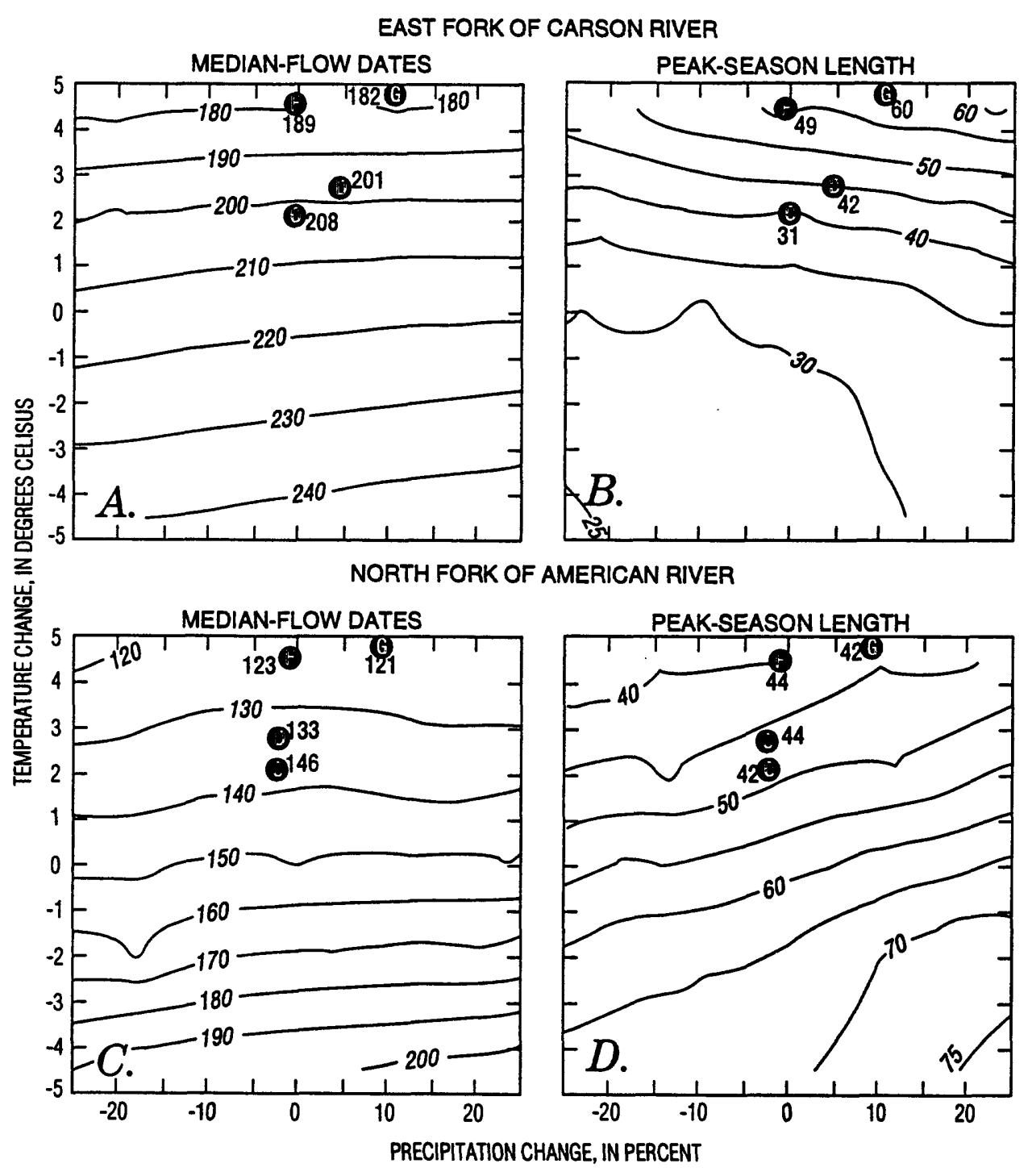

Figure 17. Simulated streamflow-timing responses to uniform-change scenarios as a function of changes in mean temperature and mean precipitation. $A$, Mean median-flow date in East Fork Carson River basin; $B$, mean peak-season length in East Fork Carson River basin; $C$, same as $A$ except in North Fork American River basin; $D$, same as $B$ except in North Fork American River basin. Labelled circles are percentage changes for four climatemodel scenarios, labelled as in figure 15. Median-flow date and peak-season length are defined in text and in table 7.

River basin scenarios so that the runoff season corresponds more and more closely to the precipitation season length.

PSL and RSL in both basins are relatively insensitive to cooler temperatures. In the Carson River basin, this insensitivity reflects a snowpack that does not persist much longer than it does now, once currentcondition springtime temperatures occur. Snowmelt in the Sierra Nevada is largely fueled by incoming shortwave solar and longwave radiation rather than by air temperature (U.S. Army Corps of Engineers, 1956; Dozier, 1987). Figures and equations in Rantz (1964) imply that solar radiation in the Sierra Nevada could melt about $40 \mathrm{~mm}$ of liquid water content per sunny spring day. At this rate, under the cooler scenarios, more than 15 to 25 days of sunny, above freezing weather would be required to melt a typical snowpack 
CHANGES IN ANNUAL SUBLIMATION AND EVAPOTRANSPIRATION, IN PERCENT

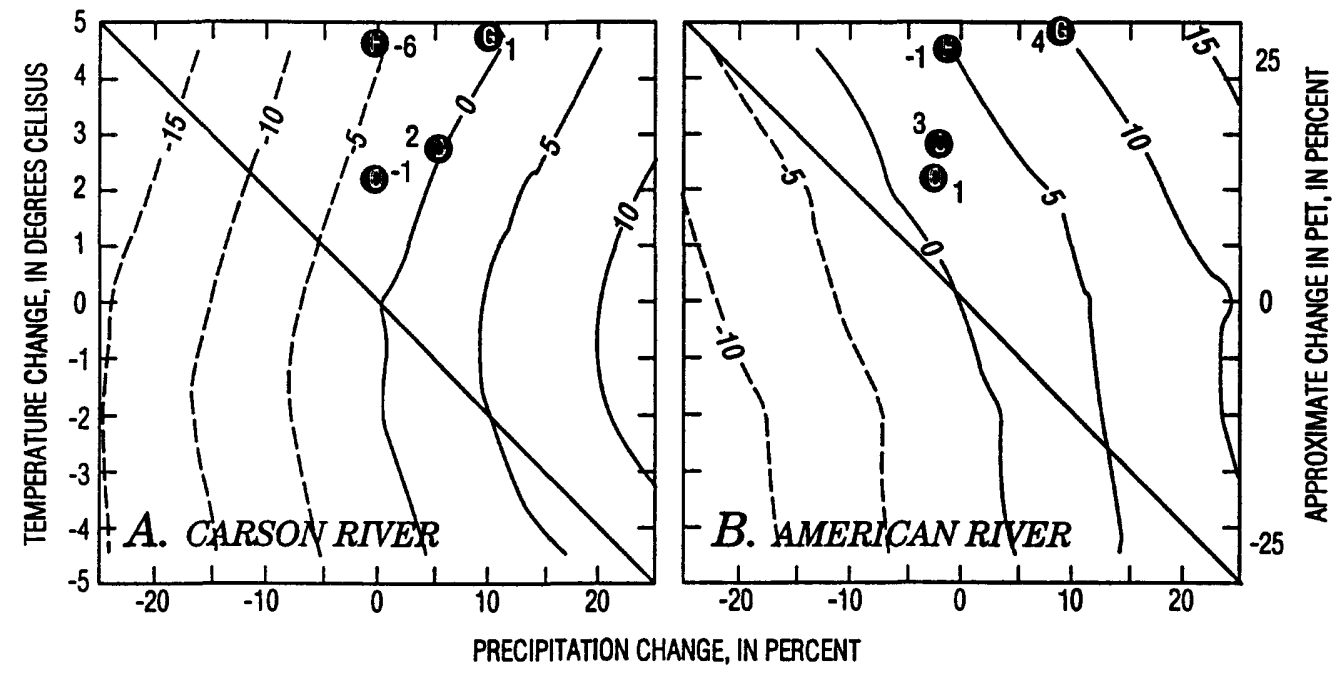

Figure 18. Simulated changes in annual sum of sublimation, evapotranspiration, and interception losses (SET) as a function of changes in mean temperature and mean precipitation. $A$, East Fork Carson River basin; $B$, North Fork American River basin. Dashed where negative. Labelled circles are percentage changes for four climatemodel scenarios, labelled as in figure 15. Approximate changes in annual potential for evapotranspiration (PET) corresponding to changes in mean temperature also are indicated. Diagonal lines represent approximately equal sensitivities to precipitation and PET changes.

in the Carson River basin, in general agreement with the lower half of figure $17 \mathrm{~b}$. In the American River basin under the cool scenarios, more and more water that would run off during the winter peak under current conditions is held in snowpack and contributes to the late spring runoff peak. A balance is struck between these two runoff peaks so that the time required for the central third of flow to run off remains nearly unchanged, although MFD arrives almost 50 days later. This balance is broken only in very wet climates (lower right quadrant of fig. 17d) when the snowpack peak lasts even farther into summer and the early runoff peak is amplified.

Annual streamflow in the Carson River responds to simultaneous changes in temperature and precipitation, mostly as a superposition of the effects of each change individually, as indicated by parallel curves in figure $15 \mathrm{~b}$. The corresponding curves for the American River (fig. 16b) are not as parallel and tend to be nearly vertical, which indicates a remarkable insensitivity to mean temperature changes.
Temperature changes directly affect the SET components of the annual water budgets, and only through that effect do they influence annual streamflow. Because SET is only a fraction of the total budget (and a small fraction in the American River basin), moderate SET responses will be reflected in weak streamflow responses. Recall that the range of temperature changes considered here corresponds to PET changes between about -25 and +25 percent. If the basins were leaky Budyko buckets (Manabe, 1969) so that SET was equally sensitive to PET and precipitation changes, contours in figure 18 would tilt to the left by $45^{\circ}$ from the vertical. In the Carson River basin model, SET responses to the very cool scenarios approximate this condition (lower third, fig. 18a). Notice, however, that SET in the Carson River basin decreases in the warming scenarios, with curves in figure 18a that approach a $45^{\circ}$ tilt to the right. SET rates in the American River basin increase, like a bucket, under the warmer scenarios and are relatively insensitive to cooler temperatures (fig. 18b). These responses must be understood in light of the storage of water by snowpacks in the two basins. 
Most importantly, notice that the changes in streamflow and SET due to temperature changes are quite small. Tilts from vertical in figures $15 \mathrm{~b}$ and $16 \mathrm{~b}$ are small, and the percentage changes in figure 18 range between about +15 and -15 percent. Recurrence-interval analyses of annual SET (not shown) indicate that these small SET responses to temperature changes pertain not just to the mean response but to responses throughout most of the 100-year simulations. However, the same analyses suggest that the small sensitivity of the streamflow (and SET) is a more robust result than are the directions of those small changes.

The SET responses are small because, even though PET rates increase (or decrease) substantially overall with the imposed mean temperature changes, moisture is released from the snowpacks and becomes available for evapotranspiration mostly during current-condition spring weather, regardless of scenario. For example, in figures 15 and 16, the times are indicated for each scenario when PET (as a surrogate for temperature) rises to the same level as the current-condition SET maximum. In each scenario, the peak SET rates (and thus the bulk of annual SET) occur at the same average "temperature." The warmer (or cooler) temperatures that occur earlier and later in the year (due to climate change) have little overall effect on annual SET because little moisture is available then. Notice in figure 15 that, in the Carson River basin, which has an abundant snowpack, SET peaks just after the peak snowmelt and runoff regardless of scenario. A similar timing relation (fig. 16) holds in the American River basin under the cooler scenarios wherein the snowpack is more abundant than under current conditions. Under current conditions in the American River basin, the SET peak is almost coincident with peak snowmelt and runoff, and in the warm scenario American River basin, the peak SET has slipped to well after the peak snowmelt and runoff. Timing of the SET maximum occurs at the same temperatures because it depends on the timing of the seasonal cycle of energy availability and of moisture availability, and both depend on the annual temperature cycle (insofar as most moisture becomes available as snowmelt in these basins). As long as the availability of both energy and moisture is tied to the arrival of currentspring temperatures, SET reaches a maximum at essentially the same temperatures regardless of what month those temperatures occur in a given scenario.
Thus, peak SET rates (and consequently the bulk of annual SET) are buffered against the influence of long-term temperature changes by the coupling of energy and moisture availability in a snowmelt-dominated basin.

In lower basins with little snowpack, runoff is generated more or less as soon as precipitation falls and moisture availability is uncoupled from energy availability. As long as precipitation timing does not change, runoff in these lower basins will be subject to more or less PET and SET, depending on the temperature during and following the winter season. In such low basins, streamflow is not buffered and would tend to decrease overall with increasing temperatures and PET. Thus, a warm basin dominated by rainfall runoff could respond to warmer temperatures like the Budyko bucket mentioned previously. The warm scenario American River basin is an example of such uncoupling. However, even in that case, the amount of water lost to SET remains somewhat buffered by shortening of the SET season as the remaining snowpack and soil moisture are exhausted earlier in the year.

Notice that the Carson River basin under the coolest scenarios also overcomes some of the buffering capacity of the winter snowpack. Figure 15d shows that SET is much subdued during winter months under the coolest scenario. The colder temperatures later in the water year also reduce even the highest summer PET rates to less than those during current-conditions late springtime (immediately after the peak SET time indicated by the " 0 " in fig. 15d). Consequently, under the cooler scenarios, moisture in the Carson River basin cannot be evapotranspired quickly enough in the early summer to compensate for the much reduced winter SET. Total SET is reduced under these cool scenarios, and annual streamflow is increased. Thus, in cold, high basins, changes in snowmelt timing may not be sufficient to buffer against streamflow responses to cooler climates. The annual SET and flow of the American River basin is buffered more under cooler temperatures because snowpack there can expand more than can snowpack in the Carson River basin (fig. 2). 


\section{RESPONSES TO GENERAL CIRCULATION CLIMATE-MODEL PROJECTIONS}

Four additional climate-change scenarios were synthesized, and responses in the two basins were simulated. The simulations mostly corroborated sensitivities identified in the uniform-change scenarios. Three of the scenarios are based on climate-model results summarized by Lettenmaier and Gan (1990, tables 5 and 6) for the GFDL climate model described by Manabe (1969), the GISS model described by Hansen and others (1983), and the OSU model described by Schlesinger (1984). The fourth scenario is based on a preliminary U.S. Bureau of Reclamation climatechange scenario for the northern Sierra Nevada (Dennis, 1991). The Dennis scenario is a qualitative extrapolation of results from several models, accounting for likely changes in such large-scale features as the Aleutian Low, winter storm tracks, and the summer subtropical high-pressure belt over the western United States.

All four scenarios involved warming of mean temperatures throughout the year. Unlike the uniformchange scenarios, however, the mean warming varies from month to month and from model to model in these scenarios. Overall, the GISS-model scenario is warmest, followed by the GFDL-model scenario. The OSU-model scenario is the coolest climate-model scenario. The Dennis scenario has a winter warming of $3^{\circ} \mathrm{C}$ and a summer warming of $2^{\circ} \mathrm{C}$. Mean annual temperatures for each scenario are indicated by their plotted positions in figures 15 through 18. Mean precipitation rates also varied from month to month. The GISS-model scenario includes a larger fall and winter increase in precipitation than do the others and an overall increase in annual precipitation of about 10 percent. In all the other scenarios, the overall changes in precipitation are small. The Dennis scenario is characterized by increased summer precipitation and unchanged winter precipitation and a small overall precipitation increase.

The timing of streamflow under the climatemodel scenarios may be compared with those of the uniform-change scenarios and with each other in figure 17. MFD is from 10 to 40 days earlier under the scenarios, and PSL is longer than under current conditions in the Carson River basin and shorter in the American River basin. Although winter snowmelt is increased in the Carson River basin, all scenarios pre- serve a prominent streamflow maximum in April and May. In the American River basin, winter streamflow is increased in all four scenarios, and spring and summer streamflows are much reduced. The timings of streamflow in both basins are similar to those yielded by the models under the uniform-change scenarios when temperature changes between about $2^{\circ} \mathrm{C}$ warmer (OSU and Dennis scenarios) and $4^{\circ} \mathrm{C}$ warmer (GFDL and GISS scenarios) are imposed. Exceptions are MFD's in the GFDL Carson River and OSU American River simulations (fig. 17), each of which arrives 10 or more days later than would be predicted from the uniform-change results due to month-to-month details of the scenarios. The OSU PSL is shorter than might be expected in both basins, perhaps reflecting enhanced springtime precipitation rates in that scenario.

Annual streamflow under the climate-model scenarios increases in the Carson River basin and decreases in the American River basin (figs. 15b and 16b). Streamflow responses in the American River basin to the relatively cool OSU and Dennis scenarios and in the Carson River basin to all scenarios are in reasonable agreement with the uniform-change scenarios. The warmest American River basin scenarios respond differently from the uniform-change scenarios because the climate-model scenarios include large increases in fall precipitation, which, in these warm scenarios, provide more water to run off during relatively low PET winter months. Annual SET changes in the GFDL and GISS scenarios in the American River also are less (positive) than would have been expected from the uniform-change results (fig. 18). In contrast, the individual runoff components and snowmelt changes under the climate-model scenarios (not shown) are all comparable to those for "similar" uniform-change scenarios in tables 7 and 8.

The effect of the more temporally detailed climate-model scenarios is minimal in the Carson River basin because the snowpack provides a long-term memory so that the basin responds mostly to longterm average changes. For example, the greater fall precipitation under the GFDL- and GISS-model scenarios is stored more-or-less through the winter until the spring snowmelt, and so precipitation timing is unimportant. In the American River basin, with its more immediate responses to precipitation inputs, annual flows are more sensitive to climate changes on time scales shorter than seasonal. 
COUPLING OF SUBLIMATIONEVAPOTRANSPIRATION AND SNOWMELT

Snowmelt and SET timing in the models and real world are tied to surface air temperatures. The temporal coincidence of peak periods of both leads to the buffering of effects on annual streamflow of mean temperature changes. When this coincidence is weakened, the buffering is weakened.

Simulated snowmelt occurs when the snowpack contains enough heat to fuel melting, and thus its timing is indirectly linked to the annual temperature cycle. The links are indirect because, as Dozier (1987, p. 153) notes, in a variety of settings, "usually the radiation balance is the dominant term [in the energy balance of a melting snowpack]." In the Sierra Nevada, the U.S. Army Corps of Engineers (1956) and Aguado (1985) note that radiation balances, rather than turbulent transfers from the atmosphere, are the dominant energy contributors. Thus radiation, not air temperature, melts Sierra Nevada snow. Snow melts earlier in warmer settings and scenarios and later in cooler ones in response to when snowpack heat balances change from (a) ones in which radiant energy acquired during daylight hours can be discharged to the atmosphere by sensible- and latent-heat fluxes over the course of a day and night to (b) ones in which these fluxes cannot transfer heat from the snowpack to the atmosphere (U.S. Army Corps of Engineers, 1956, p. 144, 297; Leavesley and others, 1983). The snowpack heat balance remains in condition " $a$ " as long as near-surface instability and upward temperature/humidity gradients are maintained so that turbulent fluxes carry thermal energy and moisture from the snowpack to the atmosphere. Usually this condition requires that the air temperature be cooler than the snowpack surface, which is near $0^{\circ} \mathrm{C}$. In contrast, if air temperature is above freezing, the near-surface atmosphere will tend to be stable (leaving only roughness-induced turbulent fluxes), and temperature/humidity gradients will favor sensible- and latent-heat transport from the air into, not out of, the snowpack. Under this latter condition, the snowpack heat balance enters condition "b," daily inputs of radiant energy are trapped in the snowpack, and snowmelt proceeds.

SET is tied to air temperatures more directly, through temperature controls on PET and through the "springtime" initiation of transpiration. In the models, PET is calculated by the Jensen-Haise procedure
(Jensen and others, 1969), and simulated rates are almost linearly related to mean temperatures. SET depends nonlinearly on temperatures, time of year, moisture availability, and other factors. In particular, transpiration is simulated as beginning anytime between March and November in the lowest HRU's and between April or May and October in the higher HRU's in the American River basin. In the Carson River basin, the allowed time period for transpiration is between April or May and November, depending on altitude. Within these periods, the particular date of the start of transpiration in a given HRU is determined by a temperature index that accumulates degree-days with maximum temperatures greater than $0^{\circ} \mathrm{C}$. Overall, SET increases earlier in warmer scenarios wherein temperatures rise above freezing earlier and increases later in scenarios in which these temperatures occur later. (For the simulations reported here, the transpiration timing criteria were not varied in response to the climate-change scenarios. In actuality, the forest community composition may change radically with climatic variability and changes (Melillo and others, 1991), and thus the time of year when transpiration can begin and end could change as part of the response of the basin to climate-change scenarios.)

In the present model, the buffering of total SET and streamflow against climate changes is the result of delicate balances between increases and decreases in SET during various seasons. SET is driven to its maximum by the energy and moisture inputs, and the simulated timings of these inputs are indirectly but definitely coupled to each other through the annual temperature cycle. Because both energy and moisture need to be available simultaneously for peak SET, relatively small, independent shifts in timing of either could affect the timing and amount of SET that eventually occurs. Even small shifts in timing could alter the character of the annual scale streamflow responses, and thus a natural concern is whether the models are accurately depicting the water-balance timings. Analyses of historical relations between climate and streamflow variability in the basins suggest that, indeed, the simulated climate-change responses are broadly realistic. For example, Duell (1994) found regression relations between streamflow and precipitation and temperature variability indicating that, in the Sierra Nevada, warmer temperatures result in greater overall runoff from high altitude basins and less runoff from middle altitude basins. A more recent analysis of 
historical streamflow variability (Risbey, 1994) has shown that (a) annual runoff from the basins of the western slope of the Sierra Nevada is largely insensitive to annual temperature variations, and (b) annual streamflow has responded to precipitation variability in approximately the same proportions as in the simulated American River basin responses to mean precipitation changes reported here.

To increase confidence in the simulated budgets and interpretations, even more realistic representations of SET and snowmelt processes may be necessary. For example, improved PET estimates could be based on a turbulent flux representation that includes explicit influences of wind and humidity (which the JensenHaise procedure does not), allowing simulation of PET responses to climate changes of both. More detailed descriptions of turbulent heat fluxes from the snow surface probably would improve estimates of both sublimation and snowmelt timing (Marks and Dozier, 1992). Sublimation from snow currently is estimated in the PRMS model as a fixed fraction of PET, and turbulent heat fluxes to the snowpack are treated in PRMS as a small function of air temperature (Leavesley and others, 1983). Even with such improvements, for climate-change studies, the likely interplay between regional temperatures, humidities, and surface winds in a climate-changed world must be simulated and currently is virtually unknown.

\section{SUMMARY AND CONCLUSIONS}

As part of the Geological Survey's Global Change Research Program, physically based, distributed-parameter, precipitation-runoff models were calibrated and verified under historic conditions. The calibrated watershed models were subjected to a variety of climate-change scenarios, and sensitivities of streamflow and other water-balance components to climate variability and change were analyzed. Two basins in the north-central Sierra Nevada were selected: the East Fork Carson River, a high altitude, leeward, semi-arid basin; and the North Fork American River, a middle altitude, windward, semi-humid basin. Models of the basins were calibrated and verified over 22- and 42-year periods, respectively. A major emphasis of the model building part of the study was to develop new methods for characterizing and partitioning basins. These techniques addressed the spatial variabilities of basin conditions and hydrologic responses. Each synthetic climate series was 100 years of daily precipitation and minimum and maximum daily temperatures. Temperatures were synthesized from normal distributions and precipitation rates from gamma distributions. Daily weather series representing regionally composited precipitation and temperatures were synthesized using the WGEN model (Richardson and Wright, 1984) and then were spatially distributed to form realistically correlated precipitation and temperature series at selected sites around and in the two basins. Uniform-change scenarios were synthesized that spanned changes between about \pm 25 percent of current mean precipitation and $\pm 4.4^{\circ} \mathrm{C}$ in both maximum and minimum temperature.

The Geological Survey's watershed model, PRMS, was used to model the basins. Basins were partitioned into hydrologically homogeneous subareas called hydrologic response units or HRU's. HRU's were delineated for the studied basins using an integrated geographic information system containing raster and vector-based data interpolated onto $100-\mathrm{m}$ grids. Data included altitudes, slopes and aspects, land cover, soils, and geology. Using pattern-recognition techniques, land areas in the grid were partitioned into noncontiguous but hydrologically similar land units based on groupings of the source data and nominal filtering to merge isolated cells into broader homogeneous land units. This method uses the definition of HRU's as discrete land units with similar sets of hydrologic properties regardless of location. This approach captures spatial detail at a finer resolution than is possible using manual methods. The physical properties affecting streamflow are quantified at the HRU level. However, the implications of spatially scattering the cell components of an HRU need to be studied further. In cases of extreme scatter, parameterization of spatial precipitation and temperature variations may become meaningless.

Although the basins are indeed leeward and windward basins, the most pronounced reason for differences in basin scale hydrology appears to be the different basin altitudes and thus different basin temperatures. Sensitivity analyses indicated that simulated streamflow is most sensitive to the precipitation correction coefficients (for snow in the Carson River basin and for rain in the American River basin), the snow threshold temperature, the monthly temperature lapse rates, and the monthly PET coefficient. Errors in 
mean annual simulated streamflow for both modeling periods averaged +10 percent of observed flows for the Carson River basin and +15 percent for the American River basin. Annual hydrographs indicated that interannual variability is quite well simulated. Flowduration plots show that simulated daily mean flows are best for above median flows, whereas performance for low flows (less than $0.30 \mathrm{~m}^{3} / \mathrm{s}$ ) is least. Although simulated monthly flows overall are satisfactory, the American model has a bias toward overestimating streamflows during the late fall and underestimating flows during the spring. The Carson model underestimates the peak (May) streamflow month by 20 percent on average. These biases may be due to errors in temperature lapse rates, which would affect the proportion of precipitation as rain versus snow, and precipitation lapse rates, which determine the spatial distribution of snowpack amount. Simulated streamflow timing in the American model for the verification period was more similar to the observed timing during the calibration period than to timing during the verification period. The historically derived water balances of the Carson and American River basins differ primarily in the timing of snowmelt and availability of soil moisture in the relation between moisture availability and PET and, thus, in streamflow timing and amount. The effects of physiography, soils, vegetation type, and density were modeled, but were not obvious factors in determining the basin scale water balances. The calibrated models appear to be sufficiently realistic and robust for simulating basin response to climate-change scenarios. However, this use is contingent upon the limitations of the model and parameterizations discussed.

The climate-change scenarios affected the simulated timing and annual streamflow volumes in the two basins. Simulated changes in streamflow timing echoed changes in snowmelt, sublimation, and evapotranspiration and were in predictable directions; specifically, warmer scenarios caused earlier runoff as snowmelt was hastened, whereas cooler scenarios postponed snowmelt and peak runoff. Wetter and drier scenarios primarily affected volumes of streamflow and other hydrologic fluxes rather than their timing. The mean median-flow date of the Carson River is delayed by 25 days under the coolest scenario and arrives $\mathbf{4 0}$ days earlier under the warmest scenarios. The median-flow date for the American River is delayed 50 days, and the entire annual hydrograph changes shape under the coolest scenarios. Under the warmest scenarios, the American River median-flow date arrives 24 days earlier on average.

Streamflow responses were nearly proportional to mean precipitation changes in the American River and were greater than proportional in the Carson River. Changes in precipitation in the Carson River basin are stored in the snowpack and released during the peak sublimation and evapotranspiration (SET) season (spring) when the basin is essentially water limited rather than energy limited. In contrast, changes in precipitation in the American River basin are reflected in runoff throughout the year. During the winter months, PET and SET from this basin are more energy limited.

Streamflow amounts were almost insensitive to mean-temperature changes in both basins. The SET peak that accompanies, and immediately follows, snowmelt is the primary loss of water other than by runoff and thus controls how much annual streamflow results from a given amount of precipitation. Under most scenarios, water is released from the snowpack and becomes available for rampant SET during periods characterized by "current-spring" temperatures and PET rates. Less SET occurs before (when the water is trapped in the snowpack) or after (when available moisture has been depleted by runoff and SET during the peak period). The year-long changes in PET imposed by the various scenarios do not affect the total SET and streamflow much because the bulk of the SET occurs at the current springtime PET rates, regardless of how warm the summers become or how cool the winters become.

Streamflow also was simulated under four climate-change scenarios based on mean monthly responses to doubled $\mathrm{CO}_{2}$ concentrations in general circulation climate models. The scenarios included temperatures that were $2^{\circ} \mathrm{C}$ to almost $5^{\circ} \mathrm{C}$ warmer than current on annual average. Precipitation differed significantly in annual total from current conditions in only one of the scenarios (GISS), but in all of them, mean precipitation varied from month to month. Streamflows simulated under these more detailed scenarios exhibited earlier snowmelt-runoff peaks, and the Carson and American Rivers responded differently to these more complicated (but overall warmer) scenarios. Mean annual streamflow increased in the Car- 
son River by 2 to 21 percent and decreased in the American River by -2 to -8 percent except in the GISS-model scenario wherein streamflow in the American River increased by 14 percent on average. Responses of the Carson River to the climate-model scenarios could be predicted from the sensitivities encountered in the uniform-change scenarios. Apparently, in this snowpack-dominated basin, snowpack provides a memory that integrates short-term variations in precipitation and temperatures, so that by snowmelt season only the season average changes are exhibited. In the American River basin with its less dominant snowpack, streamflow and SET in both of the warmest scenarios are less sensitive than would have been predicted from the uniform-change sensitivities.

Some implications of these results can be generalized along the Sierra Nevada:

- Annual streamflows would be less sensitive to changes in mean temperature than to changes in mean precipitation.

- As previous studies have noted, streamflow timing from the Sierra Nevada would be sensitive to temperature changes. Exceptions would include basins so warm (low) that they yield mostly rainfall runoff and early snowmelt runoff and basins so cold (high) that temperature changes do not affect much the amount of snow falling or snowpack duration.

- Either streamflow timing or streamflow amount (but usually not both) would be sensitive to changing mean temperatures. So long as runoff timing changes in response to temperature changes, some buffering of annual streamflow sensitivity could occur. When such timing changes are precluded, the buffer is incapacitated, and annual streamflow reflects temperature changes. Thus, basins with temperature-independent timing are most likely to respond with changes in annual streamflow.

- At basin scale, the most sensitive difference between the basins is their altitudes (and consequently, their average temperatures). Sensitivity differences due to orientation, regional aspect, slopes, and for the most part, the rain shadow were not evident at the basin scale.

- Differences in mean precipitation in the two basins appeared to have little influence on their respective sensitivities to climate change, as indicated by their sensitivities to scenarios in which precipitation was changed (for example, figs. $15 \mathrm{~b}$ and $16 \mathrm{~b}$ ). The present models indicated that simply increasing or decreasing precipitation rates generally does not cause directional or large-magnitude changes in streamflow responses. This contrasts with conclusions of Flaschka and others (1987), who considered a wider range of basins (in terms of current-condition aridity) and concluded that aridity and climate-change sensitivity are directly related. Perhaps our study of the Carson and American River basins does not provide enough range to show this effect. However, Flaschka and others explicitly neglected snowmelt processes, and thus the present study suggests that they may misrepresent the actual sensitivities.

Numerous limitations exist in the precipitationrunoff models used here and in the synthetic weather series used to drive the models. For example, (1) land cover and vegetation are not varied in response to the climate changes so the simulated sensitivities are for the current basins, not ones that have evolved to accommodate climate changes; (2) certain other calibrated features of the models that indirectly represent climatic conditions, such as mean monthly humidities, are left unchanged in the simulations; (3) the synthetic weather series used to drive the models do not maintain realistically persistent interannual variability, so multiyear streamflow responses cannot be addressed; and (4) the scenarios imposed here changed only the mean characteristics of temperature and precipitation and not their spatial structures or variabilities. Results presented in this report also were limited to discussions at the basin scale. The models simulated hydrologic fluxes in each of $\mathbf{5 0}$ hydrologic response units. Thus, much more detail remains in the model outputs. Finally, the conclusions reached depend to an unknown extent on the particular mathematical representations of hydrologic processes used in the PRMS code. PET, SET, and snowmelt are critical to the buffering effects simulated and presumably could be simulated more accurately. "Final" projections of Sierra Nevada sensitivities to climate change must await the 
application of still more detailed hydrologic models, including interactions between plant communities, basin morphology, and the hydrologic balance.

\section{REFERENCES CITED}

Aguado, E., 1985, Radiation balances of melting snow covers at an open site in the central Sierra Nevada, California: Water Resources Research, v. 21, p. 1649-1654.

Aguado, E., Cayan, D.R., Riddle, L., and Roos, M., 1992, Climatic fluctuations and the timing of West Coast streamflow: Journal of Climatology, v. 5, p. 1468-1483.

Anderson, E.A., 1968, Development and testing of snow pack energy balance equations: Water Resources Research, v. 4, no. 1, p. 19-38.

Barry, R.G., 1981, Mountain weather and climate: New York, Methuen and Co., 313 p.

Battaglin, W.A., Hay, L.E., Parker, R.S., and Leavesley, G.H., 1993, Application of a GIS for modeling the effects of climate change on water resources in the Gunnison River basin, Colorado: American Water Resources Association, Proceedings, Geographic Information Systems and Water Resources, Mobile, Alabama, March 1993, p. 203-210.

California Energy Commission, 1991, Global climate change--Potential impacts and policy recommendations: California Energy Commission Staff Report P500-91-007.

Cayan, D.R., and Riddle, L.G., 1992, Atmospheric circulation and precipitation in the Sierra Nevada: American Water Resources Association, Proceedings, Managing Water Resources During Global Change, Reno, Nevada, November 1992, p. 711-720.

Cayan, D.R., Riddle, L.G., and Aguado, E., 1993, The influence of precipitation and temperature on seasonal streamflow in California: Water Resources Research, v. 29, p. 1127-1140.

Colton, D.E., 1976, Numerical simulation of the orographically induced precipitation distribution for use in hydrologic analysis: Journal of Applied Meteorology, v. 15, no. 12, p. 1241-1251.

Dennis, A.S., 1991, Initial climate change scenario for the Western United States: U.S. Bureau of Reclamation, Global Climate Change Response Program Report, 40 p.
Dickinson, W.T., and Whiteley, H.Q., 1970, Watershed areas contributing to runoff: International Association of Hydrologic Sciences Publication 96, p. 1.12-1.28.

Dozier, J., 1987, Recent research in snow hydrology: Review of Geophysics, v. 25, p. 153-161.

Dozier, J., and Melack, J.M., 1989, Snow, snowmelt, rain, runoff, and chemistry in a Sierra Nevada watershed: Santa Barbara, University of California, Center for Remote Sensing and Environment Optics, unpublished report to California Air Resources Board, 268 p.

Duell, L.F.D., Jr., 1994, The sensitivity of northern Sierra Nevada streamflow to climate change: Water Resources Bulletin, v. 30, no. 5, p. 841859.

Flaschka, I., Stockton, C.W., and Boggess, W.R., 1987, Climate variation and surface water resources in the Great Basin region: Water Resources Bulletin, v. 23, no. 1, p. 47-57.

Folland, C.K., Karl, T., and Vinnikov, K.Y., 1991, Observed climate variations and change, in Houghton, J.T., Jenkins, G.J., and Ephraums, J.J., eds., Climate change--The IPCC scientific assessment: New York, Cambridge University Press, p. 195-238.

Frank, E.C., and Lee, R., 1966, Potential solar beam irradiation on slopes: U.S. Department of Agriculture, Forest Service Research Paper RM$18,116 \mathrm{p}$.

Gleick, P.H., 1987a, Global climatic changes and regional hydrology--Impacts and responses, in Solomon, S.I., Beran, M., and Hogg, W., eds., The influence of climate change and climatic variability on the hydrologic regime and water resources: International Association of Hydrologic Sciences Publication 168, p. 389-402. $1987 \mathrm{~b}$, The development and testing of a water balance model for climate impact assessment-Modeling the Sacramento basin: Water Resources Research, v. 23, no. 6, p. 1049-1061.

Hansen, J., Russell, G., Rind, D., Stone, P., Lacis, A., Lebedeff, S., Ruedy, R., and Travis, L., 1983, Efficient three-dimensional global models for climate studies-Models I and II: Monthly Weather Review, v. 111, p. 609-662.

Hay, L.E., Branson, M.D., and Leavesley, G.H., 1992, Simulation of precipitation in the Gunnison River Basin using an orographic-precipitation model: American Water Resources Association 28th Annual Conference and Symposium, Proceedings, TPS-92-4, p. 651-660. 
Helsel, D.R., and Hirsch, R.M., 1992, Statistical methods in water resources--studies in Environmental Science 49: The Netherlands, Elsevier Science Publishers, 522 p.

Jennings, C.W., 1977, Geologic map of California: William and Heintz Map Corporation, scale 1:750,000.

Jensen, M.E., and Haise, H.R., 1963, Estimating evapotranspiration from solar radiation: American Society of Civil Engineers, Journal of Irrigation and Drainage, v. 89, no. IR4, p. 15-41.

Jensen, M.E., Rob, D.C., and Franzoy, C.E., 1969, Scheduling irrigations using climate-crop-soil data: National Conference on Water Resources Engineering, American Society of Civil Engineers, Proceedings, $20 \mathrm{p}$.

Karl, T.R., and Riebsame, W.E., 1989, The impact of decadal fluctuations in mean precipitation and temperature on runoff--A sensitivity study over the United States: Climatic Change, v. 15, p. 423-447.

Kernodle, J.M., and Phillip, R.D., 1987, Using a geographic information system to develop a ground-water flow model, in Regional aquifer systems of the United States--Aquifers of the western mountain area: American Water Resources Association, Monograph Series 14, p. 191-202.

Kite, G., 1992, Applying a climate change scenario to a semi-distributed watershed model: 60 th Western Snow Conference, Jackson Hole, Wyoming, April 14-16, 1992, p. 113-120.

Kuhn, G., 1988, Application of the U.S. Geological Survey's precipitation-runoff modeling system to Williams Draw and Bush Draw, Jackson County, Colorado: U.S. Geological Survey

Water-Resources Investigations Report 88-4013, $38 \mathrm{p}$.

Kuhn, G., and Parker, R.S., 1992, Transfer of watershed-model parameters from calibrated to noncalibrated basins in the Gunnison River basin, Colorado: 28th Annual Conference and Symposium, American Water Resources Association, Proceedings, TPS-92-4, p. 741-759.

Leavesley, G.H., 1973, A mountain watershed simulation model: Fort Collins, Colorado, PhD. Dissertation, Colorado State University, Department of Earth Resources, 174 p.

Leavesley, G.H., 1989, Problems in snowmelt runoff modeling for a variety of physiographic and climatic conditions: Hydrological Sciences, v. 34, no. 6, p. 617-634.
Leavesley, G.H., Branson, M.D., and Hay, L.E., 1992, Using coupled atmospheric and hydrologic models to investigate the effects of climate change in mountainous regions: 28th Annual Conference and Symposium, American Water Resources Association, Proceedings, TPS-92-4, p. 691-700.

Leavesley, G.H., Litchy, R.W., Troutman, M.M., and Saindon, L.G., 1983, Precipitation-runoff modeling system--User's manual: U.S. Geological Survey Water-Resources Investigations Report 83-4238, 207 p.

Lettenmaier, D.P., and Gan, T.Y., 1990, Hydrologic sensitivities of the Sacramento-San Joaquin River basin, California, to global warming: Water Resources Research, v. 26, no. 1, p. 69-86.

Lettenmaier, D.P., and Sheer, D.P., 1991, Climatic sensitivities of California water resources: Journal of Water Resources Planning and Management, v. 117 , no. 1, p. 108-125.

Liebermann,T.D., 1991, Calculation of daily and instantaneous potential solar radiation and solar angles on sloping surfaces: 11th Annual ESRI User Conference, Proceedings, v. 1, p. 373-386.

Lillesand, T.M., and Kiefer, R.W., 1987, Remote sensing and image interpretation: New York, John Wiley, 721 p.

Manabe, S., 1969, Climate and ocean circulation, I-The atmospheric circulation and hydrology of the Earth's surface: Monthly Weather Review, v. 97, p. 739-774.

Marks, D., and Dozier, J., 1992, Climate and energy exchange at the snow surface in the alpine region of the Sierra Nevada. 1. Snow cover energy balance: Water Resources Research, v. 28, p. 3043-3054.

Melillo, J.M., Callaghan, T.V., Woodward, F.I., Salati, E., and Sinha, S.K., 1991, Effects on ecosystems, in Houghton, J.T., Jenkins, G.J., and Ephraums, J.J., eds., Climate change--The IPCC scientific assessment: New York, Cambridge University Press, p. 283-310.

Miller, D.H., 1959, Transmission of insolation through pine forest canopy as it affects the melting of snow: Versuchsw. Mitt., v. 35, p. 35-79.

Mitchell, J.F.B., Manabe, S.,Tokioka, T., and Meleshko, V., 1991, Equilibrium climate change, in Houghton, J.T., Jenkins, G.J., and Ephraums, J.J., eds., Climate change--The IPCC scientific assessment: New York, Cambridge University Press, p. 131-172. 
Nash, L.L., and Gleick, P.H., 1991, The sensitivity of streamflow in the Colorado basin to climate changes: Journal of Hydrology, v. 125, no. 3-4, p. 221-241.

Obled, C., and Rosse, B.B., 1977, Mathematical models of a melting snowpack at an index plot: Journal of Hydrology, v. 32, p. 139-163.

Ott, L., 1988, An introduction to statistical methods and data analysis: Boston, PWS-Kent Publishing, $835 \mathrm{p}$.

Press, W.H., Flannery, B.P., Teukolsky, S.A., and Vetterling, W.T., 1989, Numerical recipes--The art of scientific computation (FORTRAN version): New York, Cambridge University Press, $702 \mathrm{p}$.

Pupacko, A., 1993, Variations in northern Sierra Nevada streamflow--Implications of climate change: Water Resources Bulletin, v. 29, p. 283290.

Rantz, S.E., 1964, Snowmelt hydrology of a Sierra Nevada stream: U.S. Geological Survey Water-Supply Paper 1779-R, 36 p.

Richardson, C.W., and Wright, D.A., 1984, WGEN--A model for generating daily weather variables: U.S. Department of Agriculture, Agricultural Research Service Report ARS-8, 83 p.

Risbey, J.S., 1994, On the use of climate models to access the impacts of regional climate change in water resources: Massachussets Institute of Technology, Ph.D. thesis, 213 p.

Rosenbrock, H.H., 1960, An automatic method of finding the greatest or least value of a function: Computer Journal, v. 3, p. 175-184.

Schlesinger, M.E., 1984, Climate model simulation of CO2-induced climate change, in Advances in Geophysics: San Diego, Academic Press, v. 26, p. 141-235.

Smith, J.L., 1974, Hydrology of warm snowpacks and their effects upon water delivery--some new concepts in Advanced concepts and techniques in the study of snow and ice resources: Washington, D.C., National Academy of Sciences Press, p. 7689.

Stewart, J.H., Carlson, J.E., and Johannesen, D.C., 1982, Geologic map of the Walker Lake one degree by two degree quadrangle, California and Nevada: U.S. Geological Survey Miscellaneous Field Studies Map MF-1382-A, scale 1:250,000.

Swift, L.W., Jr., 1976, Algorithm for solar radiation on mountain slopes: Water Resources Research, $v$. 12 , no. 1 , p. $108-112$.
Todini, E., 1980, The preservation of skewness in linear disaggregation schemes: Journal of Hydrology, v. 47, p. 199-214.

Troendle, C.A., 1991, Global change--Can we detect its effect on subalpine hydrographs?:

Proceedings, 59th Annual Western Snow Conference, Juneau, Alaska, April 12-15, 1991, p. 1-7.

Troutman, B.M., 1985, Errors and parameter estimation in precipitation-runoff modeling. 1. Theory: Water Resources Research, v. 12, no. 8, p. 1195-1213.

Tsuang, B.J., and Dracup, J.A., 1991, Effect of global warming on Sierra Nevada mountain snow storage: Proceedings, Western Snow Conference, $12 \mathrm{p}$.

U.S. Army Corps of Engineers, 1956, Snow hydrology--Summary of snow investigations: U.S. Army Corps of Engineers Technical Summary, North Pacific Division, Portland, Oregon, $437 \mathrm{p}$.

U.S. Department of Agriculture, 1991, State soil geographic data base (STATSGO)--Data users guide: U.S. Department of Agriculture, Soil Conservation Service Publication no. 1492, 84 p.

U.S. Geological Survey, 1986, U.S. Geodata--Land use and land cover digital data from 1:250,000 and 1:100,000 scale maps: National Mapping Program Technical Instructions, Data Users Guide, v. 4, 36 p. 1987, U.S. GeoData--Digital elevation models: National Mapping Program Technical Instructions, Data Users Guide, v. 5, 38 p.

Waggoner, P.E. (ed.), 1990, Climate change and U.S. water resources--Report of the American Association for the Advancement of Science panel on climatic variability, climate change and the planning and management of U.S. water resources: American Association for the Advancement of Science: New York, John Wiley, $496 \mathrm{p}$.

Woodcock, C.E., Jakabhazy, V., Macomber, S., Ryherd, S., Strahler, A., and Yecheng, W., 1990, Timber inventory using Landsat Thematic Mapper imagery and canopy reflectance models: Proceedings, 23rd International Symposium on Remote Sensing of the Environment, Bangkok, Thailand, April 18-25, 1990, v. 2, p. 937-948.

World Meteorological Organization, 1986, Intercomparison of models on snowmelt runoff: Geneva, Switzerland, World Meteorological Organization Operational Hydrology Report 23, Publication 646, 430 p. 